\title{
OPTIMIZATION AND EFFECTIVENESS OF THE PLACEMENT OF ENERGY DISSIPATORS IN RC FRAME STRUCTURES
}

\author{
D. Domínguez ${ }^{(*)}$ \\ (1) Associate Professor, University of Talca, ddominguez@utalca.cl \\ (*) Department of Engineering and Building Management, University of Talca, Curicó zip code, 3340000 Chile \\ Corresponding author: ddominguez@utalca.cl (David Domínguez,Santos) \\ ORCID: https://orcid.org/0000-0001-6664-9011 (Dominguez).
}

\begin{abstract}
This document explores and analyzes the optimization of the use and placement of energy dissipators in the bays of frame structures located in seismic zones. This study may be applied to new and existing buildings. In order to do this, three RC frames of 5,10 and 15 stories are analyzed and compared, using four brace arrangements (Chevron braces San Andrés cross and diagonal braces (two cases)). The behavior of these frames is analyzed in terms of modal parameters, capacity curves (Push-over) and dynamic analyses (Time-History). For the study, the Lorca record of mean magnitude was used, also in this case, hysteretic dissipators have been used as they are cheap and easy to install solutions. The efficiency of the energy dissipators is improved as the frames increase in height. In the lower height frames, the use of braced solutions without any device improves the structural behavior. The ductility of all frames increases with the placement of dissipators.
\end{abstract}

Keywords: Energy Dissipators; Hysteretic Devices; Chevron braces; Frame structures; Push-over; Braces

\section{Introduction}

A significant number of buildings across the world are highly vulnerable to strong earthquakes (Bonett 2003; Gueguen 2013; Clementi et al. 2016; Adhikari et al. 2019), mainly due to the lack of design requirements in previous design codes and, less intensely, to construction deficiencies and the high level of inherent uncertainty of earthquakes (Dominguez Santos et al. 2012; López-Almansa et al. 2013; Fikri et al. 2019). Different constructive solutions are used to solve these problems.

Traditional techniques mainly consist of the design of stronger and more rigid structures (Foraboschi 2016). These solutions have proved effective in reducing damage after strong seismic events. However, there are important objections: (i) the cost is generally excessive, (ii) the architectural and functional impact is important, (iii) the ductility of the structure, due to the fact that in cases of strong excitations, the damage is concentrated on the main elements of the structures (walls, beams and columns) and, (iv) the high weight of the buildings that imply an increase in seismic forces. To address these limitations, two innovative approaches have been proposed: base isolator (Marano and Greco 2003; Yingli et al. 2007; Tena-Colunga et al. 2009; Liu et al. 2011; Bîtcă et al. 2015; Tena-Colunga 2015; Hadad et al. 2017) and energy dissipator (Restrepo and Rahman 2007; Segués 2014).

A base isolator consists of incorporating elements outside the structure that are highly flexible in the horizontal direction (commonly referred to as isolators) to the foundation of the building. In this way, the building becomes more flexible, significantly lengthening its fundamental period (Su et al. 1989; Marano and Greco 2003; Liu et al. 2011). This device decouples the building from the horizontal movement of the ground; therefore, the shear force on the design base is drastically reduced. On the other hand, since most of the stress is concentrated in the isolation layer, the incorporation of additional damping to the construction is highly feasible with this device, thus improving its structural performance. Base isolation has been thoroughly investigated and used in many countries of the world, particularly in Chile and Japan. Currently, there are isolated buildings with this system that have performed satisfactorily under strong earthquakes, confirming the effectiveness of this solution. However, seismic isolation still has some important limitations (Su et al. 1989; Marano and Greco 2003; Tena-Colunga and Pérez-Osornio 2006): (i) isolators must be able to withstand the weight of the building, (ii) this technology cannot be considered for high buildings, due to the weight that must be resisted and the long fundamental period of high-rise buildings, (iii) its use in soft soils, due to the effects of soil-structure interaction, (iv) the permanent displacements produced (which can be enormous in buildings near active faults), causing the design and dimensions of the isolators to be very large, and (v) the isolation is not effective against gusts of wind. 
Furthermore, power sinks are another innovative strategy, which overcomes most of the limitations of base isolation. Energy dissipators (Mazza 2019; Nuzzo et al. 2019) are devices external to the main structural system, in that they do not participate in supporting the gravity load, they are only efficient against horizontal loads (wind, earthquake etc.) (Domínguez Santos et al. 2015). These devices are connected to the structure, so that they undergo significant deformations produced by movements between floors. Through these deformations, the heatsinks absorb energy, thus protecting the rest of the construction. They can be considered to be 'structural fuses' (i.e. the 'weakest links') of the building (López-Almansa and Oller 2014). Furthermore, these elements can be easily replaced after being damaged by strong earthquakes.

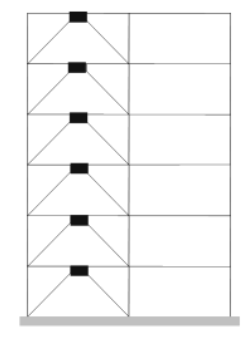

(a) Chevron braces with/without dissipator energy

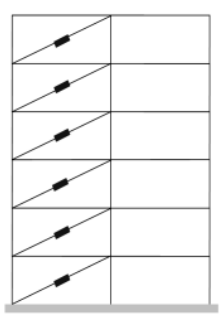

(b) Diagonal braces with/without dissipator energy

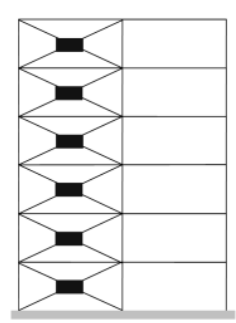

(c) Double diagonal braces 'San Andres Croix' with/without dissipator energy

Fig. 1 Braced solutions considered, with and without power dissipators

Fig. 1 shows the location of the energy dissipators for seismic protection of the building structures, connected to the main structure of the building using additional bracing systems (Fig. 1(a) to 1(c)). Due to the different locations of these devices in the frames using rigid steel elements connected to the main structure, this study performs a comparative analysis between the solutions mostly used in construction with and without dissipators, in order to determine the efficiency and seismic effectiveness of each proposed solution. The solutions selected for this study will depend on the type of brace used: (i) Chevron braces ('V' inverted), (ii) San Andrés cross (double diagonal), and (iii) single diagonal.

Given the great diversity of dissipators on the market (hysteretic (Mazza 2019; Nuzzo et al. 2019), frictional, viscoelastic materials, viscous fluids, superelastic (shape memory alloys) among others), it was decided to use hysteresis devices based on yielding metal. It is a simple, easy, quick to install technological system (it only requires reinforcing elements such as the braces outside the main structure) which is economic, since it does not require excessive maintenance. Due to these characteristics, these devices could be used in a massive and feasible way in seismically active countries, due to their low construction costs. Due to the independence that these devices have from the main structure of the building, this technology is considered to be very versatile due to the ease of installation, whether in new construction or renovation. Across the world, several buildings have been equipped with this class of device, experiencing strong seismic demands and performing satisfactorily; for example, the Titanium Building (La Portada) in Santiago, Chile, behaved properly under the Maule earthquake of 8.8 degrees in 2010. In Chile, due to its great seismicity, there have been previous investigations on the use of energy dissipators (Bin 1995; Ou and Wu 2001; Tena-Colunga and Hernández-Ramírez 2020).

\section{Prototype frames}

\subsection{General considerations}

In this study, three RC (Masi 2003) frames (of 5, 10 and 15 floors) were selected, in order to represent a significant number of vulnerable buildings around the world. The primary structural elements of the frames (beams and columns) analyzed in this study were designed and dimensioned following the European regulations for structural concrete, EC-2 (2004), and earthquake-resistance, EC-8 (2005), in addition to the Spanish Concrete Regulations, EHE-08 (2008), and earthquakeresistance, NCSE-02 (2002). The design of these frames was complemented by some aspects of the American regulations for structural concrete, ACI 318 (2008).

These frames were analyzed for a medium-hard soil type (soil type $\mathrm{C}$ ), located in a moderate seismic zone, whose acceleration is $\mathrm{a}_{\mathrm{g}}=0.12 \mathrm{~g}$, corresponding to the location of the seismic record used in the dynamic analyses.

The dimensions used in the design of the different structural elements of the frames (columns and beams) are presented in Table 1. 


\begin{tabular}{|c|c|c|c|c|}
\hline & $\begin{array}{c}\text { 5-story } \\
\text { Columns } \\
\left(\mathrm{cm}^{2}\right)\end{array}$ & $\begin{array}{c}\text { 10-story } \\
\text { Columns } \\
\left(\mathrm{cm}^{2}\right)\end{array}$ & $\begin{array}{c}\text { 15-story } \\
\text { Columns } \\
\left(\mathrm{cm}^{2}\right)\end{array}$ & $\begin{array}{c}\text { Beams } \\
\left(\mathrm{cm}^{2}\right)\end{array}$ \\
\hline 1-floor $(0-4 m)$ & $40 \times 40$ & $60 \times 60$ & $70 \times 70$ & \multirow{6}{*}{$30 \times 40$} \\
\hline 2-floor (4-7m) & $40 \times 40$ & $60 \times 60$ & $70 \times 70$ & \\
\hline 3-floor $(7-10 \mathrm{~m})$ & $40 \times 40$ & $60 \times 60$ & $70 \times 70$ & \\
\hline 4-floor $(10-13 \mathrm{~m})$ & $30 \times 30$ & $60 \times 60$ & $70 \times 70$ & \\
\hline 5-floor $(13-16 \mathrm{~m})$ & $30 \times 30$ & $50 \times 50$ & $70 \times 70$ & \\
\hline 6-floor (16-19m) & -- & $50 \times 50$ & $60 \times 60$ & \\
\hline 7-floor (19-22m) & -- & $50 \times 50$ & $60 \times 60$ & \multirow{9}{*}{$30 \times 40$} \\
\hline 8 -floor $(22-25 \mathrm{~m})$ & -- & $30 \times 30$ & $60 \times 60$ & \\
\hline 9-floor $(25-28 \mathrm{~m})$ & -- & $30 \times 30$ & $60 \times 60$ & \\
\hline 10 -floor $(28-31 \mathrm{~m})$ & -- & $30 \times 30$ & $50 \times 50$ & \\
\hline 11-floor $(31-34 \mathrm{~m})$ & -- & -- & $50 \times 50$ & \\
\hline 12-floor $(34-37 \mathrm{~m})$ & -- & -- & $50 \times 50$ & \\
\hline 13-floor $(37-40 \mathrm{~m})$ & -- & -- & $30 \times 30$ & \\
\hline 14-floor $(40-43 \mathrm{~m})$ & -- & -- & $30 \times 30$ & \\
\hline 15-floor $(43-46 \mathrm{~m})$ & -- & -- & $30 \times 30$ & \\
\hline
\end{tabular}

Table 1 Dimensions of columns and beams

As discussed in Section 1, the objective of this work was to compare the seismic resistance behavior of the primary structural elements (beams and columns) using hysteretic energy dissipators (based on the plasticization of metals) and using different braced arrangements in the placement of these devices. Furthermore, the results were compared with the same structural solution, but without taking into account the arrangement of dissipators. For this, a 4-bays portal frame was used, using 4 different brace arrangements at the external bays:

1. Frame structure 'braced' in the extreme bays, with inverted ' $V$ ' reinforcement or Chevron Braces (Fig. 3a). The nomenclature used for this solution is CHB.

2. Frame structure 'braced' in the extreme bays, with reinforcement of two diagonals 'San Andrés Cross' (Fig. 3b). The nomenclature used for this solution is SAB.

3. Frame structure 'braced' at the extreme bays, with a diagonal reinforcement, placed with the same arrangement (Fig. 3c). The nomenclature used for this solution is EDB.

4. Frame structure 'braced' at the extreme bays, with a diagonal reinforcement, placed with a symmetrical arrangement (Fig. 3d). The nomenclature used for this solution is SDB.

In all cases, the main elements of the structure (columns and beams) were designed using the structural dimensions detailed in Table 1, i.e. without taking into account the strength of the devices used. With this criterion, a comparative structural study was carried out for the four proposed solutions. For this, non-linear static calculations were made (Push-Over) (Elnashai 2001; Chopra and Goel 2004) and the ductility, maximum base shear and maximum displacements of the highest floor of the proposed structures were compared, establishing the structural damage of the frames. The RISK-UE method (Barbat et al. 2016) was used to determine the damage index of the structures for the different levels of structural performance: Immediate Occupation (IO), Life Safety (LS) and Collapse Prevention (CP), as established in FEMA 356 (2000). These analyses were complemented by dynamic analyses (Time-History) (Wilson et al. 1972; Vamvatsikos and Cornell 2002), using the Lorca seismic register (Martínez-Díaz et al. 2011; Oterino et al. 2012; Giner-Robles et al. 2012) (Spain) in the NS direction that occurred in 2010. The purpose of these analyses was to compare the damage produced by the maximum structural displacements in the last floors of the frames and the absolute accelerations.

\subsection{Description and design of traditional frames}

The RC frame analyzed was composed of 4 bays, 5 meters long, with a regular elevation and section configuration. The design of these corresponded to the design criteria of the vast majority of the seismic resistance standards: uniform and regular shapes without overhangs throughout their entire height; the first floor was $4 \mathrm{~m}$ high and the remaining floors $3 \mathrm{~m}$ high. Therefore, the total heights of the 5,10 and 15-story structures were 16, 31 and $46 \mathrm{~m}$, respectively.

Each frame comprised 5 columns joined together by high beams $\left(b_{w}<h_{w}\right)$. The columns had a square section that varied between $30 \mathrm{~cm}$ x $30 \mathrm{~cm}$ and $70 \mathrm{~cm}$ x $70 \mathrm{~cm}$, increasing their section on the lowest floors for each of the frames, as detailed in Table 1. The dimensions of all the beams were $b_{w}=30 \times h_{w}=40 \mathrm{~cm}$, adding the effective width portion of the slab specified in article 8.4.1.8 of the ACI Standard 318 (Fig. 2) (2008); $28 \mathrm{~cm}$ long $\left(h_{b}\right), 12 \mathrm{~cm}$ thick $\left(h_{f}\right)$ in the external beam of the frame 
$\left(h_{b}<4 h_{f}\right)$ and $28 \mathrm{~cm}$ thick on each side of the internal beams of the frame $\left(b_{w}+2 h_{b}<b_{w}+8 h_{f}\right)$, thus favoring the 'diaphragm effect' that must occur in the structural behavior of buildings.
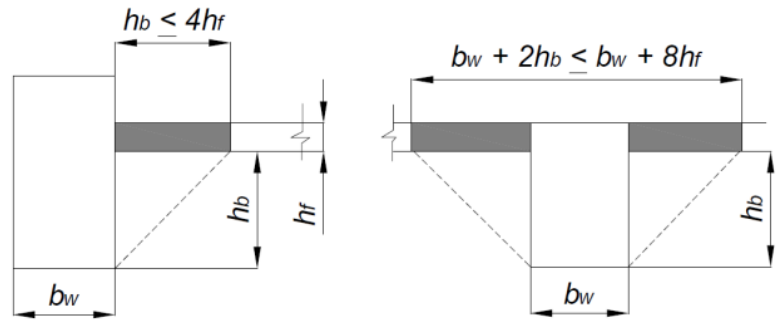

Fig. 2 Effective widths of the beams (ACI 318)

Regarding the braced frames, HSS (hollow square section) profiles of grade A36 steel were used in ASTM (1958). The sections were of dimensions $100 \mathrm{~mm} \times 3 \mathrm{~mm}, 160 \mathrm{~mm} \times 10 \mathrm{~mm}$ and $200 \mathrm{~mm} \times 12 \mathrm{~mm}$, for the 5,10 and 15 -story buildings, respectively. The brace positions are shown in Fig. 3.

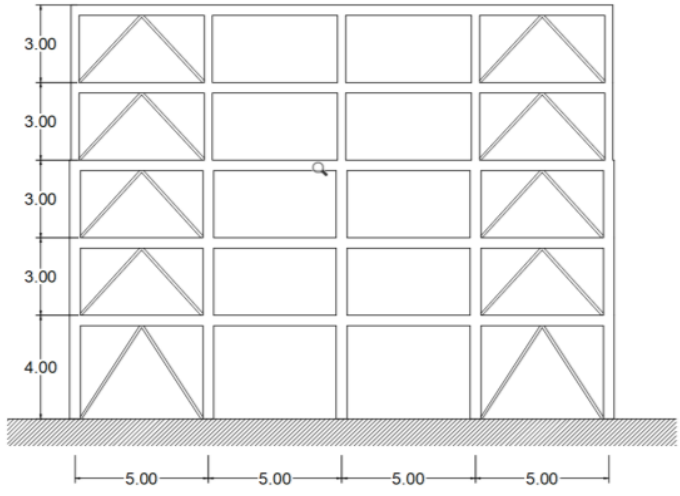

a) With Chevron braces (CHB)

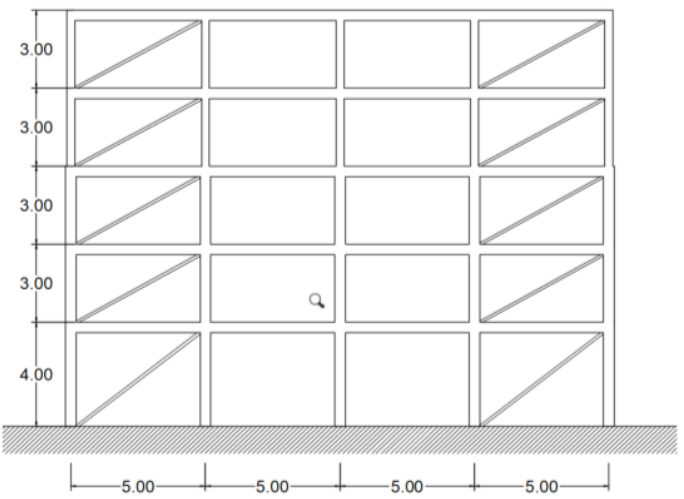

c) With diagonal braces (EDB)

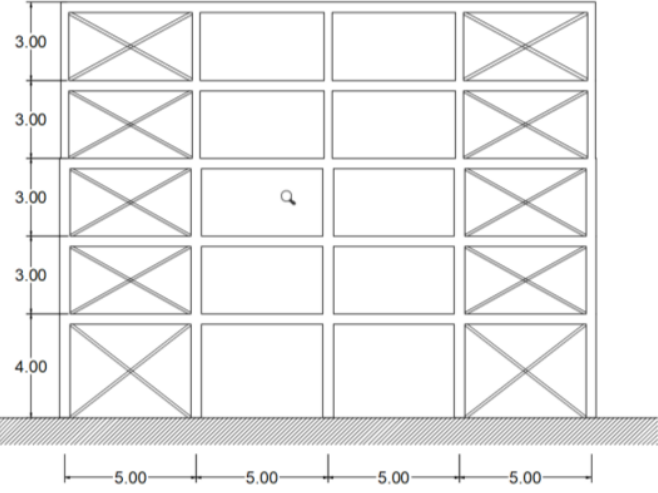

b) With San Andrés cross (SAB)

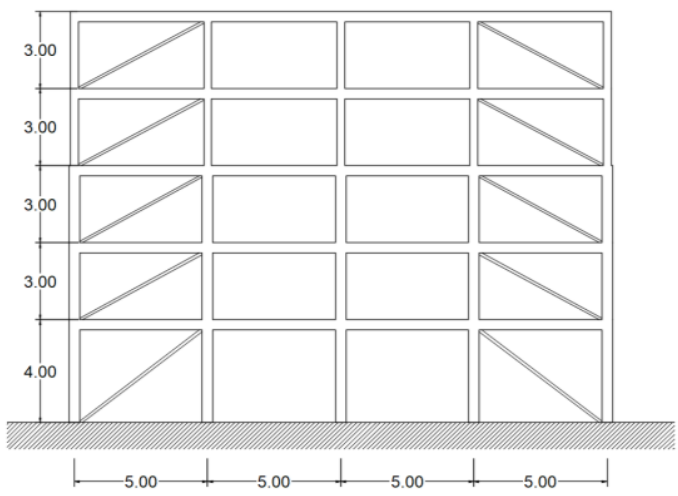

d) With diagonal braces (SDB)

Fig. 3 Arrangement of braces on the frames

\subsection{Materials}

Following the criteria of the European and American Regulations, the use that the analyzed frames had is residential, administrative or equivalent, corresponding to a use overhead of $L=2 \mathrm{kN} / \mathrm{m}^{2}$. The characteristic value of the compressive strength of the concrete was $f_{c}{ }^{\prime}=30 \mathrm{MPa}$ and the yield strength of the reinforcing steel was $f_{y k}=500 \mathrm{MPa}$. Grade A36 steel was used to make the braces.

\subsection{Structural modeling}

The static and dynamic behavior of the prototype frames were simulated with the SeismoStruct software package (2020). The modeling of these buildings was done with finite bar elements, implementing the formulations developed by Bathe and Wilson 
(1976), Spacone et al. (1996) and Neuenhofer and Filippou (1997). The cross sections of each structural element (columns and beams) and the characteristics of the construction materials were specified following the models proposed by Bento et al. (2008).

Given the symmetry and regularity of the analyzed frames, their structural behavior could be represented by flat models. The columns and beams were represented by nonlinear finite element bars (Bathe and Wilson 1976; Spacone et al. 1996; Neuenhofer and Filippou 1997); the nonlinearities were concentrated in the plastic hinge joints (Inel and Ozmen 2006; Scott and Fenves 2006; Bae and Bayrak 2008) located at the ends of each bar, equivalent to $15 \%$ of the total length of each element according to previous research (Inel and Ozmen 2006; Scott and Fenves 2006; Bae and Bayrak 2008) and the joints between the columns and the beams were considered to be rigid. The hysteretic behavior of each bar was taken into account, in terms of the dimensions, the shapes of the structural sections, the existing reinforcement and the characteristics and properties of the materials. The accuracy of the structural behavior of each element depended on the number of fibers in which they were divided. For this study, the discretization used for each section was 300 fibers.

Due to cracking of the tensioned concrete, the initial stiffness of structural members was reduced, based on gross sectional parameters, but the concrete modulus of elasticity was reduced as indicated in EHE-08 (2008) and EC-8 (2005). The sectional behavior was based on the average properties of the materials, instead of the characteristic ones. In the case of concrete, the average compressive strength is $f_{c}=f_{c}{ }^{\prime}+8=38 \mathrm{MPa}$.

The braces were calculated as elements, following the same plastic criteria taken into account for the primary elements (beams and columns). To finish, the global damping factor considered for each structure was $5 \%$.

\subsection{Fundamental Period, Weight and Seismic forces of the prototype frames}

For each prototype frame, a linear modal analysis was carried out, with seismic weight corresponding to a dead load and $30 \%$ of the live load (EC-8 2005). Table 2 and Table 3 show the weight and the fundamental period of the frame, respectively.

\begin{tabular}{|c|c|c|c|c|}
\hline No. of stories & $\begin{array}{c}\text { Weight } \\
\text { CHB (KN) }\end{array}$ & $\begin{array}{c}\text { Weight } \\
\text { SAB (KN) }\end{array}$ & $\begin{array}{c}\text { Weight } \\
\text { EDB (KN) }\end{array}$ & $\begin{array}{c}\text { Weight } \\
\text { SDB (KN) }\end{array}$ \\
\hline 5 & 2986 & 3017 & 2971 & 2971 \\
\hline 10 & 6566 & 6720 & 6486 & 6486 \\
\hline 15 & 10543 & 10906 & 10357 & 10357 \\
\hline
\end{tabular}

Table 2 Weight $W(\mathrm{kN})$ of the prototype frames

\begin{tabular}{|c|c|c|c|c|}
\hline No. of stories & $\begin{array}{c}\text { Fundamental Period } \\
\text { CHB (s) }\end{array}$ & $\begin{array}{c}\text { Fundamental Period } \\
\text { SAB }(\mathrm{s})\end{array}$ & $\begin{array}{c}\text { Fundamental Period } \\
\text { EDB }(\mathrm{s})\end{array}$ & $\begin{array}{c}\text { Fundamental Period } \\
\text { SDB }(\mathrm{s})\end{array}$ \\
\hline 5 & $0.623 / 0.514$ & $0.505 / 0.502$ & $0.691 / 0.632$ & $0.671 / 0.615$ \\
\hline 10 & $0.841 / 0.732$ & $0.696 / 0.692$ & $0.923 / 0.857$ & $0.909 / 0.831$ \\
\hline 15 & $1.186 / 1.089$ & $0.952 / 0.941$ & $1.321 / 1.242$ & $1.307 / 1.215$ \\
\hline
\end{tabular}

Table 3 Fundamental Period (s) of the prototype frames

Once the weights and the fundamental periods of each analyzed frame were obtained, the seismic forces were obtained from the European seismic resistance standard, EC-8 (2005). The analysis was carried out for a soil (Type C), with a seismic acceleration of $0.12 \mathrm{~g}$, corresponding to the Lorca (Spain) zoning and a building of normal importance. The seismic forces for each of the floor frames analyzed are represented in Table 4.

\begin{tabular}{|c|c|c|c|}
\hline Floor & $\begin{array}{c}\text { Seismic Forces } \\
\text { CHB } \\
(\mathrm{kN})\end{array}$ & $\begin{array}{c}\text { Seismic Forces } \\
\text { SAB } \\
(\mathrm{kN})\end{array}$ & $\begin{array}{c}\text { Seismic Forces } \\
\text { EDB and SDB } \\
(\mathrm{kN})\end{array}$ \\
\hline 1 & 15 & 16 & 12 \\
\hline 2 & 26 & 27 & 21 \\
\hline 3 & 38 & 38 & 30 \\
\hline 4 & 49 & 50 & 39 \\
\hline 5 & 60 & 62 & 48 \\
\hline
\end{tabular}

Continue table... 
Continue table...

\begin{tabular}{|c|c|c|c|}
\hline Floor & $\begin{array}{c}\text { Seismic Forces } \\
\text { CHB } \\
(\mathrm{kN})\end{array}$ & $\begin{array}{c}\text { Seismic Forces } \\
\text { SAB } \\
(\mathrm{kN})\end{array}$ & $\begin{array}{c}\text { Seismic Forces } \\
\text { EDB and SDB } \\
(\mathrm{kN})\end{array}$ \\
\hline 1 & 7 & 7 & 6 \\
\hline 2 & 12 & 13 & 10 \\
\hline 3 & 17 & 18 & 14 \\
\hline 4 & 22 & 23 & 22 \\
\hline 5 & 27 & 29 & 26 \\
\hline 6 & 32 & 34 & 31 \\
\hline 7 & 36 & 39 & 35 \\
\hline 8 & 41 & 45 & 39 \\
\hline 9 & 46 & 50 & 43 \\
\hline 10 & 51 & 55 & Seismic Forces \\
\hline & EDB and SDB \\
$(\mathrm{kN})$
\end{tabular}

Table 4 Seismic forces of the frames analyzed using EC-8

As expected, the results in Table 4 show how the seismic forces were considerably reduced for the frames with diagonal braces. This is due to the lower mass of the frame and the longer period. On the other hand, the maximum seismic forces correspond to the most rigid buildings, those with San Andrés cross bracing.

\section{Lorca earthquake}

Despite its moderate magnitude $\left(M_{w}=5.1\right)$, the Lorca earthquake (Martínez-Díaz et al. 2011; Oterino et al. 2012; GinerRobles et al. 2012) constitutes one of the seismic movements with the greatest destructive power recorded in Spain in the last decade. This severity seems to be due to the low hypocentral depth (about $2 \mathrm{~km}$ ) and the almost zero distance between the epicenter and the city center of Lorca (2.9 km from the seismological station). The earthquake left 9 people dead, 167 injured (3 seriously) and 40,000 homeless, causing significant material damage. Fig. 4a and 4b represent the accelerograms of the horizontal components (N-S, E-W) of the most severe events in the Lorca registry (Dominguez Santos et al. 2014; Dominguez Santos et al. 2016). 


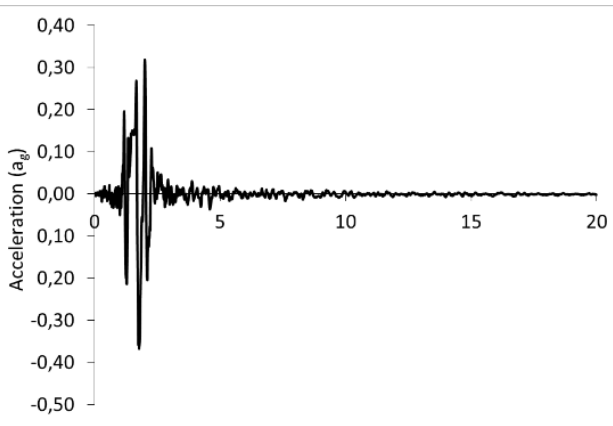

N-S direction

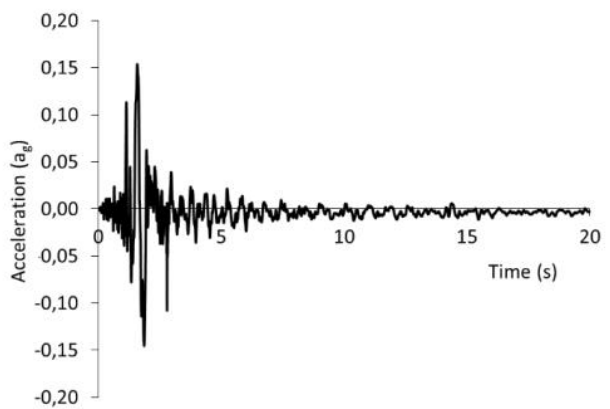

E-W direction

\section{Fig. 4 Lorca accelerogram}

Fig. 4 shows that the horizontal register of the Lorca earthquake was markedly impulsive, particularly in its North-South component. For this component, Manfredi's dimensionless index took the value $I D=2.57$ and for the east-west component $I D=3.53$. The $I D$ index is defined as the quotient between the integral of the square of the acceleration throughout the total duration and the product of the maximum values of acceleration and speed. This index quantifies the presence of speed pulses, i.e. of impulsive registers with directivity effects generated by proximity to the fault. Usually, $I D$ values less than 10 are considered to correspond to impulsive registers with proximity failure effects. On the other hand, the Arias Intensity (AI) was also obtained for each of the directions (Instrumental Seismic Intensity), consisting of a parameter that serves to determine the seismic risk of an area. $\mathrm{AI}$ is an instrumental measure used to determine the damage that an earthquake causes to structures and buildings. The values obtained for this earthquake in the N-S direction was $0.527 \mathrm{~m} / \mathrm{s}$ and for the E-O it was $0.117 \mathrm{~m} / \mathrm{s}$.

Fig. 5 represents the response spectra of absolute acceleration $S_{a}$ of the accelerograms corresponding to Fig. 4. This figure also shows the response spectrum of the Spanish Standard (2002) for Lorca seismic acceleration $\left(a_{b}=0.12 \mathrm{~g}\right)$ for hard soil (Type I according to NCSE-02). It can be seen how, for both components, the prescriptions of the NCSE-02 are clearly exceeded for almost all periods of interest (especially the North-South direction).

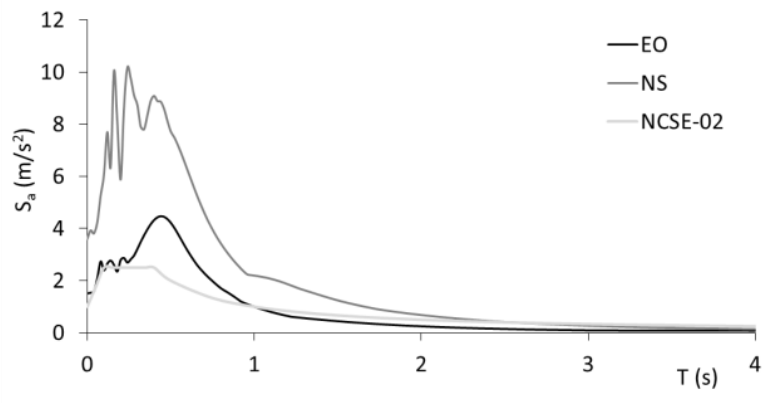

Fig. 5 Response spectra corresponding to the Lorca and NCSE-02 for $a_{b}=0.12 g$ (Dominguez Santos et al. 2014; Dominguez Santos et al. 2016)

\section{Damping system}

\subsection{Overall description}

The proposed damping system consisted of using additional bracing systems and installing hysteretic energy dissipators between these elements and the main structure, as indicated in Fig. 1. For example, the solution using chevron braces (Fig. 6) was considered next. As shown in Fig. 6, devices were installed on all of the floors; this guaranteed an even behavior along the frame height (vertical uniformity). Noticeably, dissipators could be freely moved along the enclosure of the building without disturbing the symmetry and torsional strength. 


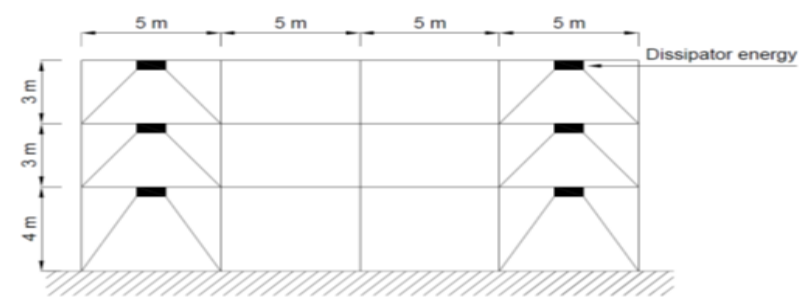

Fig. 6 Distribution of dissipative devices

\subsection{Hysteretic dissipators}

Since the final goal of this research is to promote the use of hysteretic energy dissipators (Mazza 2019; Nuzzo et al. 2019) for the seismic protection of vulnerable buildings, no specific recommendations for any specific device are given. For instance, the devices that were installed in the Titanium building might be adequate. In this case, the hysteretic behavior of any dissipator was characterized and modeled using three major parameters: yielding force, initial (elastic) stiffness and postyielding ratio. The values used in this study are shown in table 5.

To determine the necessary parameters in the modeling of the energy dissipators, the method explained in Section 4.3 and detailed in Benavent-Climent (2011) was used. The results of the parameters that determine the design of each dissipator for each floor of the frames are described below.

\begin{tabular}{|c|c|c|c|c|c|c|c|c|c|}
\hline & \multicolumn{3}{|c|}{$\begin{array}{c}\text { Dissipators } \\
\text { 5-story }\end{array}$} & \multicolumn{3}{c|}{$\begin{array}{c}\text { Dissipators } \\
\text { 10-story }\end{array}$} & \multicolumn{3}{c|}{ 15-story } \\
\hline Floor & K $(\mathrm{kN} / \mathrm{cm})$ & $\mathrm{F}_{\mathrm{y}}(\mathrm{kN})$ & Post-f & $\mathrm{K}(\mathrm{kN} / \mathrm{cm})$ & $\mathrm{F}_{\mathrm{y}}(\mathrm{kN})$ & Post-f & K $(\mathrm{kN} / \mathrm{cm})$ & $\mathrm{F}_{\mathrm{y}}(\mathrm{kN})$ & Post-f $\mathrm{y}$ \\
\hline 1 & 256.95 & 85.84 & 0.078 & 475.00 & 258 & 0.094 & 730.00 & 361 & 0.01 \\
\hline 2 & 128.48 & 79.69 & 0.068 & 228.85 & 248 & 0.35 & 590.00 & 351 & 0.015 \\
\hline 3 & 122.37 & 69.39 & 0.068 & 132.50 & 237 & 0.146 & 240.00 & 340 & 0.09 \\
\hline 4 & 104.55 & 53.75 & 0.032 & 135.29 & 224 & 0.085 & 335.00 & 328 & 0.06 \\
\hline 5 & 133.83 & 31.23 & 0.014 & 95.24 & 208 & 0.06 & 305.00 & 315 & 0.02 \\
\hline 6 & -- & -- & -- & 67.35 & 189 & 0.025 & 135.00 & 299 & 0.015 \\
\hline 7 & -- & -- & -- & 61.63 & 165 & 0.026 & 140.00 & 282 & 0.011 \\
\hline 8 & -- & -- & -- & 50.00 & 136 & 0.027 & 196.00 & 262 & 0.0079 \\
\hline 9 & -- & -- & -- & 43.34 & 100 & 0.024 & 105.71 & 234 & 0.011 \\
\hline 10 & -- & -- & -- & 54.17 & 55 & 0.053 & 120.00 & 212 & 0.009 \\
\hline 11 & -- & -- & -- & -- & -- & -- & 85.72 & 181 & 0.0091 \\
\hline 12 & -- & -- & -- & -- & -- & -- & 78.27 & 146 & 0.0011 \\
\hline 13 & -- & -- & -- & -- & -- & -- & 72.73 & 104 & 0.009 \\
\hline 14 & -- & -- & -- & -- & -- & -- & 93.34 & 56 & 0.006 \\
\hline 15 & -- & -- & -- & -- & -- & -- & 85.34 & 37 & 0.005 \\
\hline
\end{tabular}

Table 5 Values that determine the modeling of the design dissipators

\subsection{Design of the dissipative devices}

The energy that can be dissipated in the whole building in a given direction cannot be obtained by merely adding the capacities of each story, it depends on the distribution of the dissipated energy and on the accidental eccentricities between their centers of mass and rigidity. To cope with this issue, a number of formulations to select the variation of the design stiffness and yielding forces of the steel members along the building height have been proposed; in this paper, the approach in BenaventCliment (2011) is considered. This formulation aims to obtain a uniform distribution of the cumulative ductility $\eta$ in each level along the building height. The yielding shear force on the $i$-th floor $\left(V_{\mathrm{yi}}\right)$ is normalized with respect to the weight above that floor: 


$$
\alpha_{\mathrm{i}}=\frac{V_{\mathrm{yi}}}{\sum_{\mathrm{j}=\mathrm{i}}^{\mathrm{N}} W_{\mathrm{j}}}
$$

In equation (1), $W_{\mathrm{j}}$ is the weight of the $j$-th floor and $N$ is the number of floors. This formulation considers the influence of the vertical distribution of the lateral stiffness of the main structure. The variation of $\alpha_{i}$ obeys an exponential equation:

$$
\frac{\alpha_{\mathrm{i}}}{\alpha_{1}}=\exp \left[\left(1-0.02 \frac{k_{1}^{\mathrm{t}}}{k_{\mathrm{N}}^{\mathrm{t}}}-0.16 \frac{T_{\mathrm{F}}}{T_{\mathrm{G}}}\right) \frac{i-1}{N}-\left(0.5-0.05 \frac{k_{1}^{\mathrm{t}}}{k_{\mathrm{N}}^{\mathrm{t}}}-0.3 \frac{T_{\mathrm{F}}}{T_{\mathrm{G}}}\right)\left(\frac{i-1}{N}\right)^{2}\right]
$$

In equation (2), $k_{\mathrm{i}}^{\mathrm{t}}$ is the lateral stiffness of the $i$-th floor, $T_{\mathrm{F}}$ is the fundamental period of the building in the direction under consideration and $T_{\mathrm{G}}$ is the corner period of the $V_{\mathrm{E}}$ design spectrum (Fig. ); $T_{\mathrm{G}}$ separates initial and horizontal branches.

With all this, the obtained values of $\alpha_{1}$ are $0.02,0.03$ and 0.05 , for the frames of 5, 10 and 15 floors. In the same way, the K1 values are 5,10 and 15 respectively.

\section{Seismic demand}

Seismic demand is given as an input and hysteretic energy $\left(E_{\mathrm{I}}\right.$ and $E_{\mathrm{H}}$ ), expressed in terms of equivalent velocities $V_{\mathrm{E}}$ and $V_{\mathrm{D}}$ according to $V_{\mathrm{E}}=\sqrt{2 E_{\mathrm{I}} / m}$ and $V_{\mathrm{D}}=\sqrt{2 E_{\mathrm{H}} / m}$, where $m$ is the mass of the building. For practical, energy-based, earthquake-resistant design, $V_{\mathrm{E}}$ is obtained from the available design energy spectra and $V_{\mathrm{D}}$ is estimated from $V_{\mathrm{E}}$ through empirical expressions of the ratio $V_{\mathrm{D}} / V_{\mathrm{E}}: V_{\mathrm{D}}=V_{\mathrm{E}}\left(V_{\mathrm{D}} / V_{\mathrm{E}}\right)$. Since design spectra are commonly derived after an important number of representative, strong seismic ground motions, this strategy can provide an adequate level of safety. Among other research, Benavent-Climent et al. 2002 proposed design energy input spectra for moderate seismicity regions and BenaventCliment et al. (2010), Yazgan (2012) and López-Almansa et al. (2013) proposed design energy input spectra for moderate-tohigh seismicity regions, based on Colombian and Turkish records, respectively. These $V_{\mathrm{E}}$ input energy spectra depend on the soil characteristics, the seismic design acceleration, the magnitude of the expected earthquakes and the type of seismic input (relevance of velocity pulses); conversely, they do not depend on the mass or on the damping parameters. Moreover, except in the short period range, the $V_{\mathrm{E}}$ spectra are also independent of the assumed hysteretic constitutive law. A number of researchers (Akiyama 1985; Kuwamura et al. 1994; Fajfar and Vidic 1994; Decanini and Mollaioli 2001; Benavent-Climent et al. 2002; Yazgan 2012; López-Almansa 2013) have derived empirical expressions of the ratio $V_{\mathrm{D}} / V_{\mathrm{E}}$; such expressions depend on the soil type, the structural damping, the fundamental period of the structure, and the displacement or cumulative ductility. The obtaining of inputs and hysteretic energy for the prototype buildings to be protected with energy dissipators is described next.

\subsection{Input energy in terms of equivalent velocity $\left(V_{E}\right)$.}

In this study, the seismic demand is derived after the design spectra proposed in Benavent-Climent et al. 2002, Yazgan 2012 and López-Almansa et al. 2013. These spectra depend on the soil characteristics (stiff / soft), the seismic design acceleration, the magnitude of the expected earthquakes $\left(M_{\mathrm{s}} \leq 5.5\right.$ and $\left.M_{\mathrm{s}}>5.5\right)$ and the type of seismic input (pulse-like / non pulse-like). As for the soil type, rock is broadly identified as stiff soil. The studies in Benavent-Climent et al. 2002, Yazgan 2012 and López-Almansa et al. 2013 were carried out assuming a design acceleration of $0.4 \mathrm{~g}$. Concerning the magnitude, given the high seismicity proposed in this study, it can be conservatively assumed that $M_{\mathrm{s}}>5.5$. With respect to the presence of velocity pulses, since velocity pulses are more common in strike-slip mechanisms, the expected accelerograms will be mainly nonpulse-like. For stiff and soft soil conditions, the $V_{\mathrm{E}}$ spectra proposed in Benavent-Climent et al. 2002, Yazgan 2012 and LópezAlmansa et al. 2013 are shown in Fig. 7(a) and Fig. 7(b), respectively. For linear analyses $(\mu=1, \mu$ being the displacement ductility), the spectra in Fig. contain an initial, linearly growing branch in the short period range, a plateau in the mid period range and a descendant branch in the long period range. The corner periods and the spectral ordinates for the plateau are indicated in Fig. 7; the exponents of the descending branches are 1.2 and 0.65 for stiff and soft soil, respectively. Except in the short period range, the input energy is a highly stable quantity (Akiyama 1985) with respect to the hysteretic and damping parameters of the structure under consideration. Therefore, for nonlinear behavior $(\mu>1)$ the only required modification is an increase in the initial growing branch slope. This slope increase will result in a reduction of the lowest corner period; for instance, for $\mu=20$ the ratio between both slopes is 1.41 and 1.56 for stiff and soft soil, respectively. Therefore, the corner periods become $0.18 / 1.41=0.12 \mathrm{~s}$ (stiff soil) and $0.28 / 1.56=0.18 \mathrm{~s}$ (soft soil), as shown in Fig. 7. Both the linear and nonlinear spectra are characteristic, i.e. they correspond to the $95 \%$ percentile, and refer to a 475 year return period. The values of $V_{\mathrm{E}}$ for the corresponding prototype buildings are obtained, replacing the fundamental periods in the spectra of Fig. 7. Noticeably, all of the periods lie in the plateau (mid period range). 


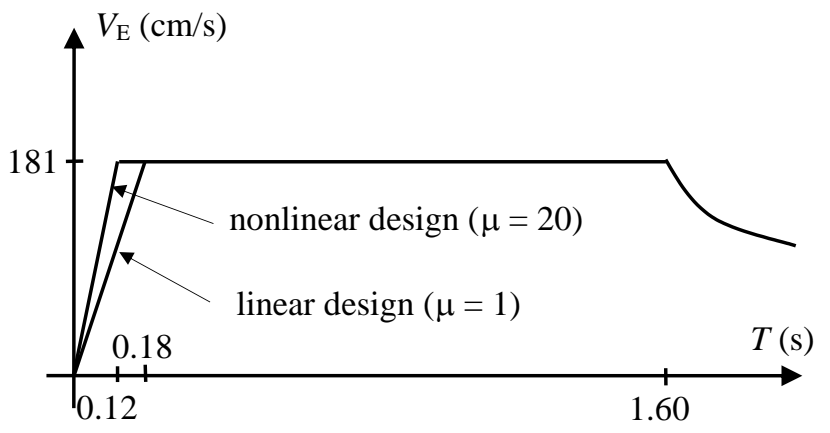

(a) Linear/nonlinear spectrum for stiff soil

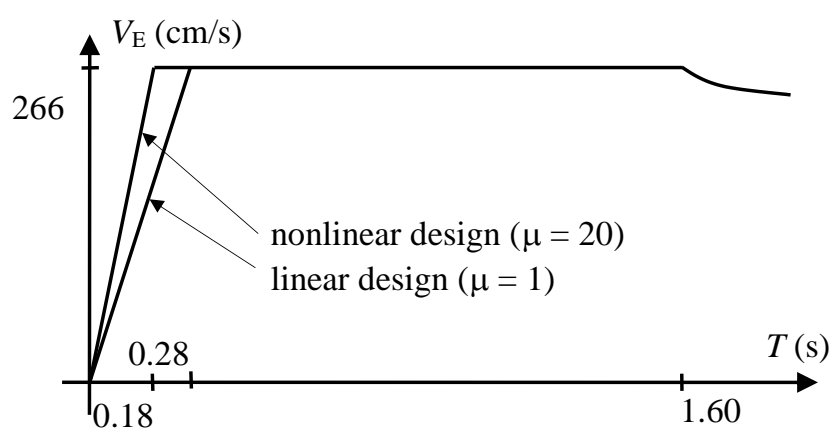

(b) Linear/nonlinear spectrum for soft soil

Fig. 7 Input energy design spectra (Yazgan 2012; López-Almansa et al. 2013)

\subsection{Hysteretic energy $\left(E_{H}\right)$.}

The $V_{\mathrm{D}}$ spectrum is commonly obtained by multiplying the $V_{\mathrm{E}}$ spectrum by a convenient value of the $V_{\mathrm{D}} / V_{\mathrm{E}}$ ratio; such a ratio depends mainly on the damping factor $\zeta$, the displacement ductility $\mu$ and the building fundamental period $T_{\mathrm{F}}$. References Yazgan 2012 and López-Almansa et al. 2013 contain linear regression studies providing average expressions for $V_{\mathrm{D}} / V_{\mathrm{E}}=a$ $T_{\mathrm{F}}+b$ where coefficients $a$ and $b$ depend on $\zeta$ and $\mu$. The hysteretic energy can be obtained after the equivalence equation $V_{\mathrm{D}}=\sqrt{2 E_{\mathrm{H}} / m}$. In this study, coefficients $a$ and $b$ were selected for $\zeta=0.05$ and $\mu=10$ : for both rock and soft soil, $a=0.88$ and $b=-0.054$ (Yazgan 2012; López-Almansa et al. 2013). The values of $\zeta$ and $\mu$ were chosen to correspond to average conditions. Noticeably, a more accurate analysis would require an iterative process in terms of ductility demand, however, it should be emphasized that, for values of $\mu$ higher than 5 , the ratio $V_{\mathrm{D}} / V_{\mathrm{E}}$ is rather insensitive to that parameter.

\section{Nonlinear analysis (Push-over)}

2D static analyses (Push-over) (Elnashai 2001; Chopra and Goel 2004) have been performed using the model described in Section 2, using the SeismoStruct program (2020).

Fig. 8, 9 and 10 show the capacity curves (Displacement-Base shear) for each prototype analyzed (with and without devices). The vertical and horizontal axes of the figures show the relationship between the base shear force on the ground floor and the displacement at the top floor frames. Furthermore, in each of the figures, the damage limits established by the RISK-EU method are represented with a vertical line (Barbat et al. 2016), delimiting Minor damage (DL), Moderate damage (DM), Severe damage (DS) and Full damage (DC). On the other hand, in each of the curves, 3 points appear that indicate the different levels of structural performance for the different return periods: Immediate Occupation (IO), Life Safety (LS) and Collapse Prevention (CP), as specified by FEMA 356 (2000) and Comartin et al. (1996). With these representations, the structural state in which each of the frames is for each level of damage will be obtained, according to the displacement that each frame has on the highest floor.

Static, nonlinear (pushover) analysis was carried out using the numerical models described in Section 2.4; second-order effects are accounted for by a P-delta analysis. The variation of the pushing forces along the height of the frame is triangular. Fig. 8, Fig. 9 and Fig. 10 show the capacity curves in terms of base shear force and displacement at the top floor for the 5, 10 and 15-story frames, respectively. 
With energy dissipators

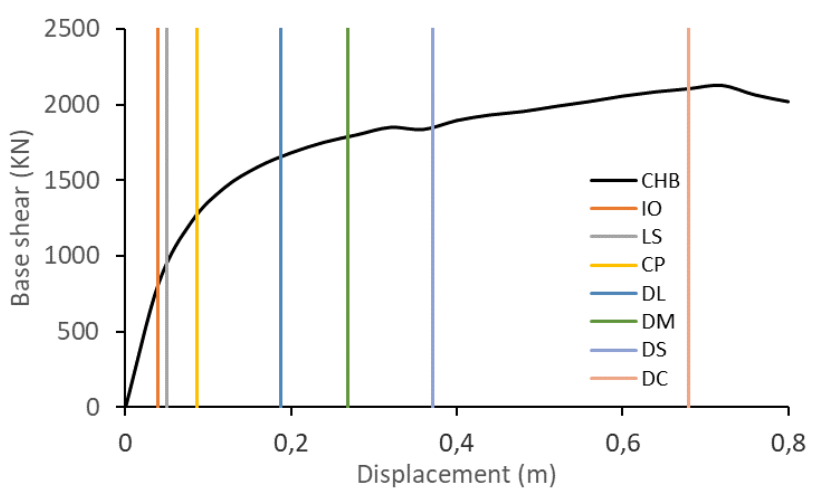

Without energy dissipators

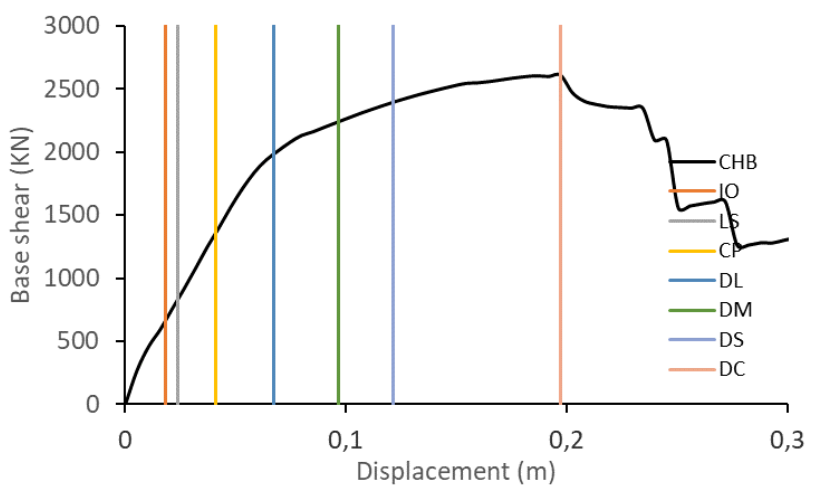

Frame with 'Chevron' braces (CHB)
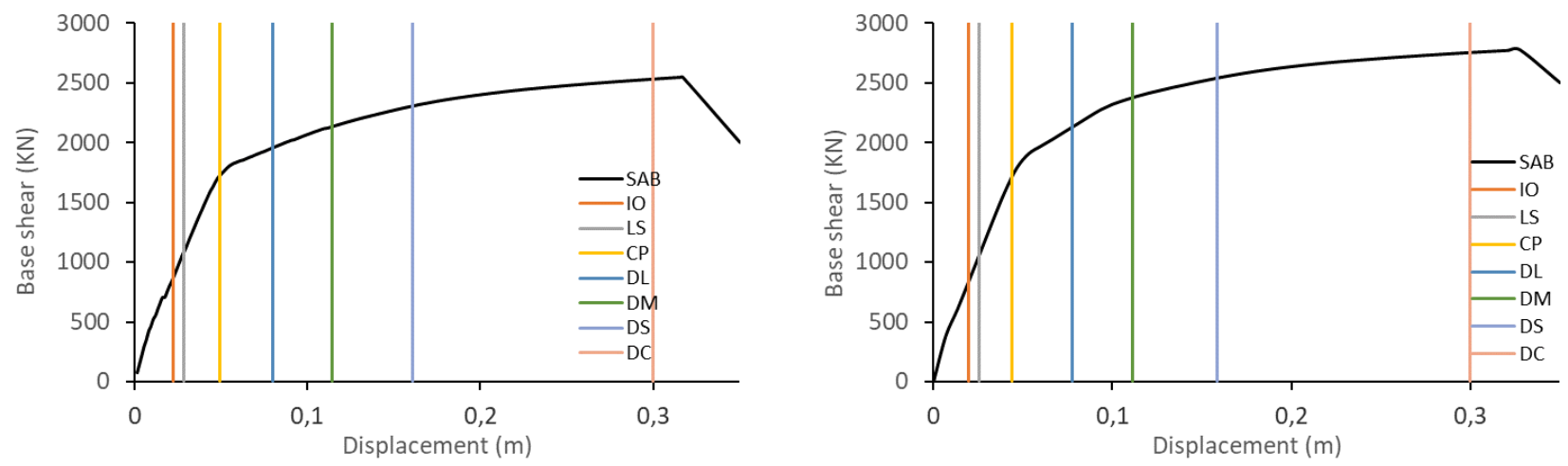

Frame with double diagonal braced 'San Andres cross' (SAB)
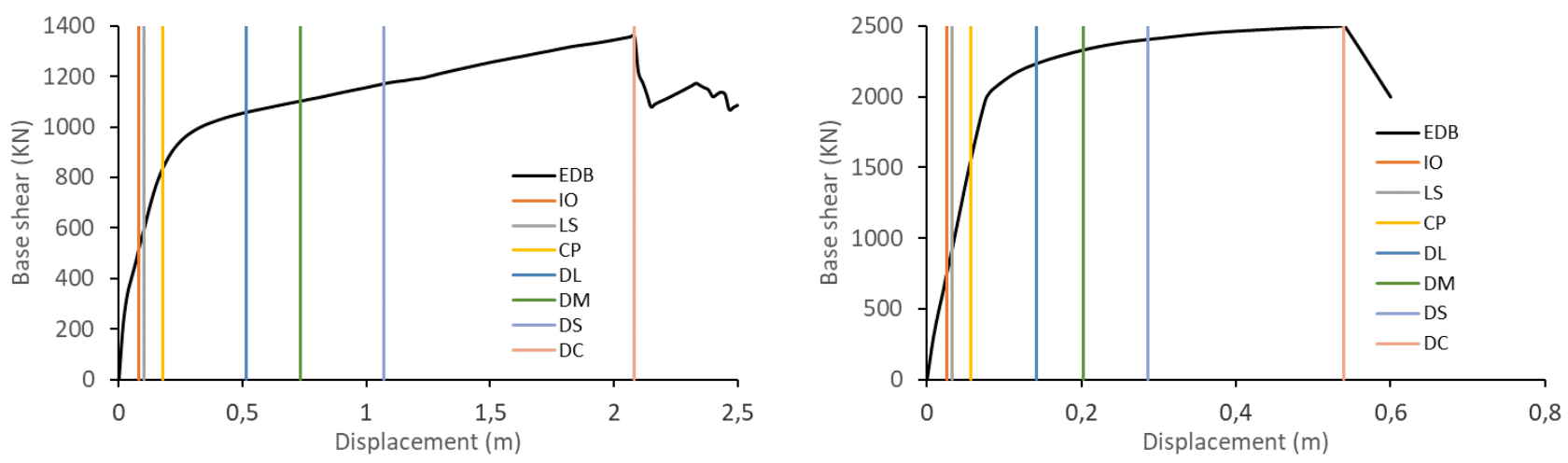

Frame with diagonal braced 'same direction' (EDB) 

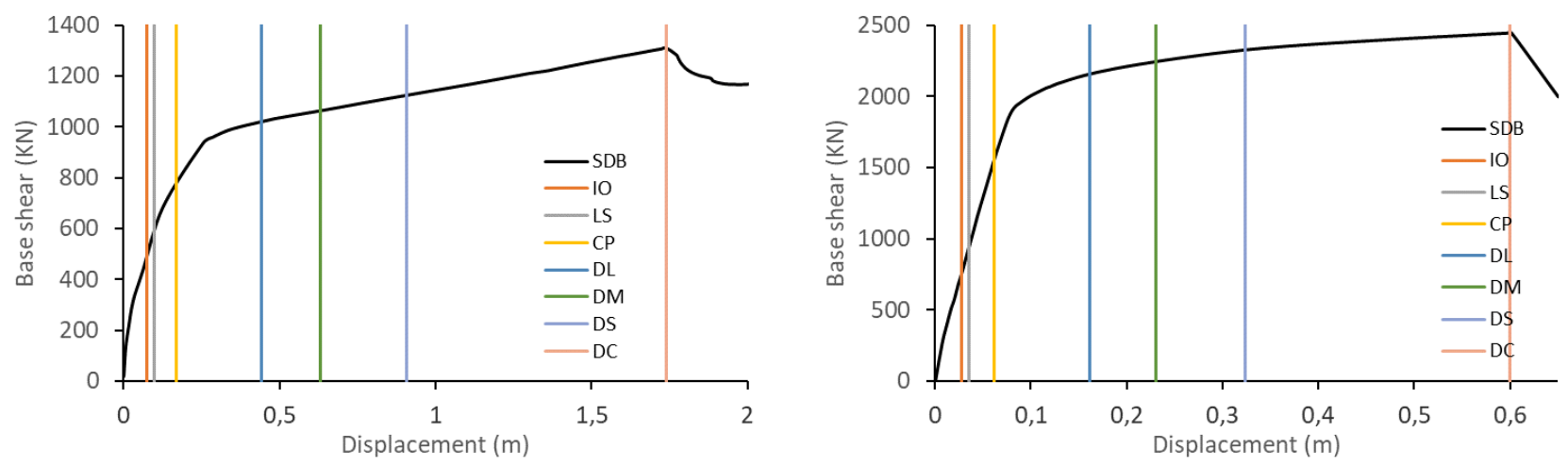

Frame with diagonal braced 'symmetrical direction' (SDB)

Fig. 8 Capacity curves of the 5-story frames (base shear - displacement)

With energy dissipators

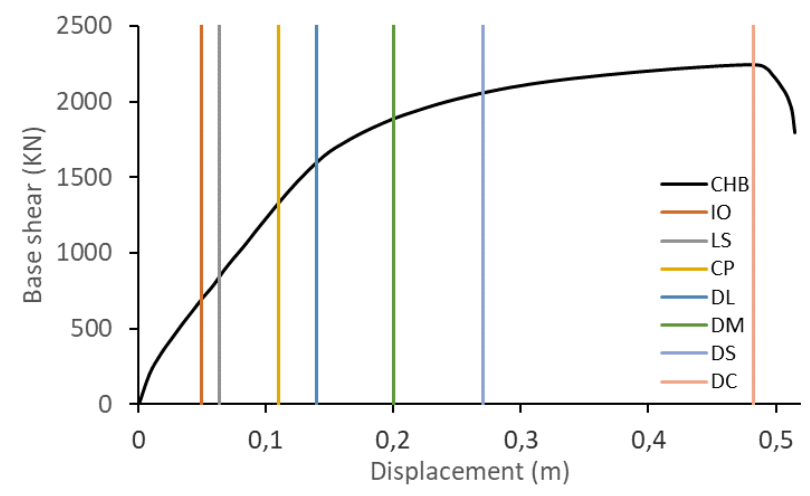

Without energy dissipators

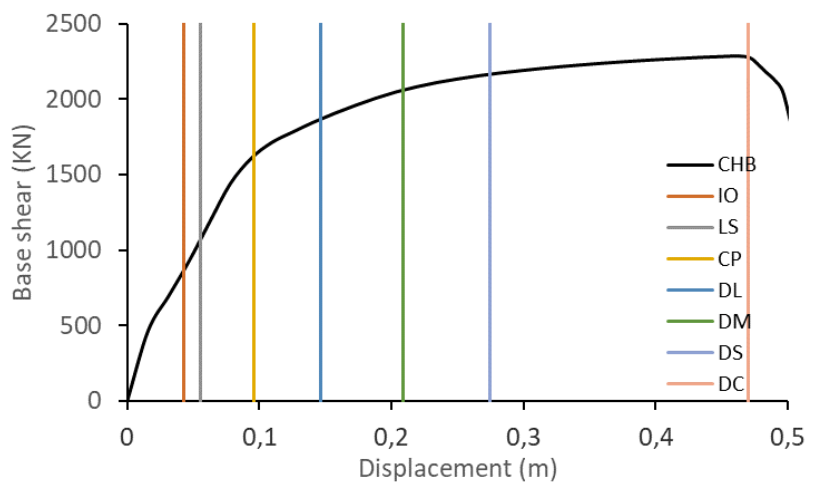

Frame with 'Chevron' braces (CHB)
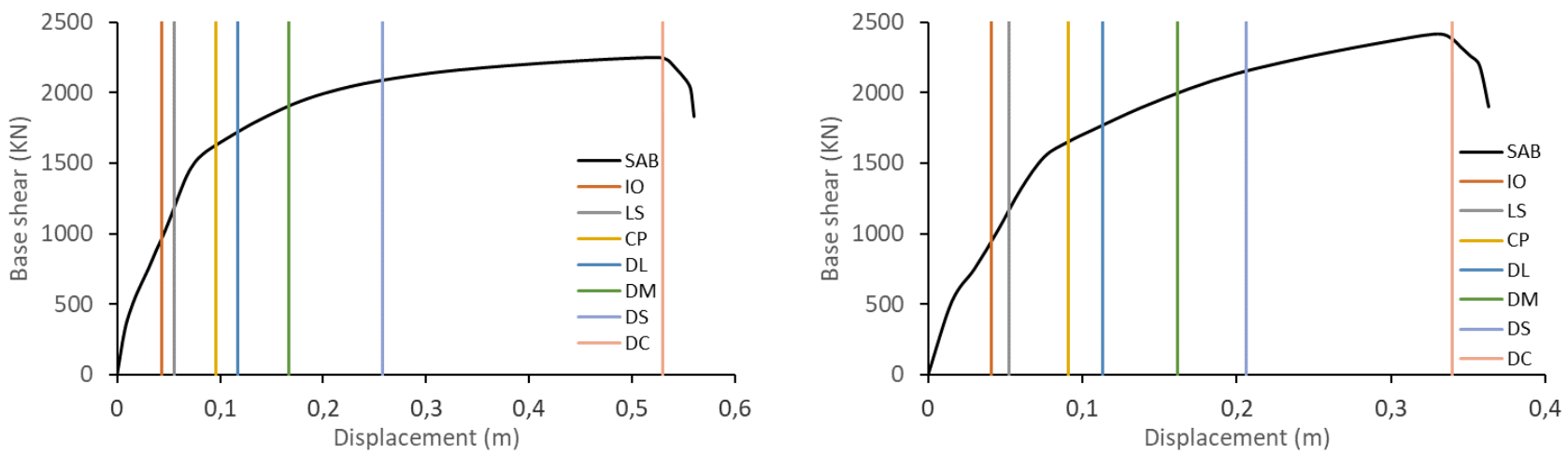

Frame with double diagonal braced 'San Andres cross' (SAB) 

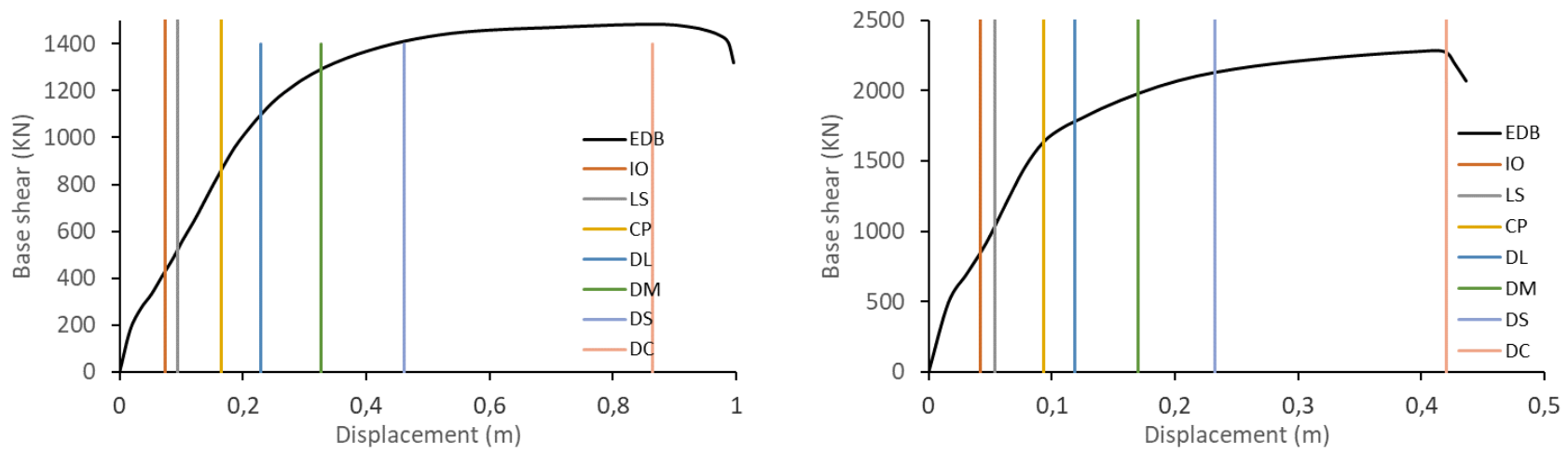

Frame with diagonal braced 'same direction' (EDB)
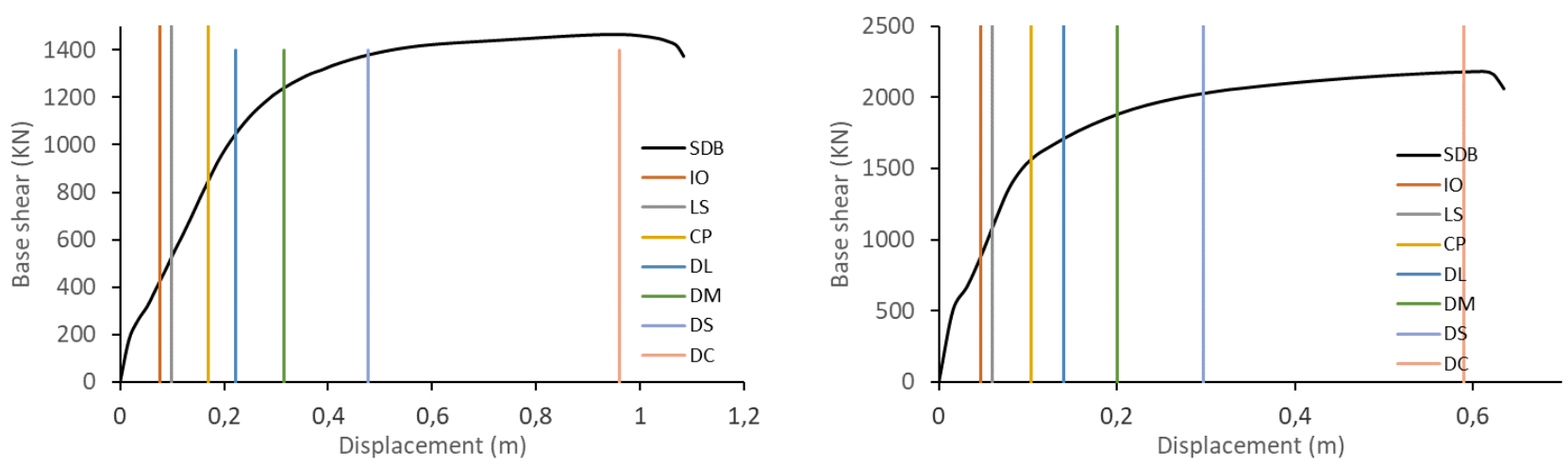

Frame with diagonal braced 'symmetrical direction' (SDB)

Fig. 9 Capacity curves of the 10-story frames (base shear - displacement)

With energy dissipators

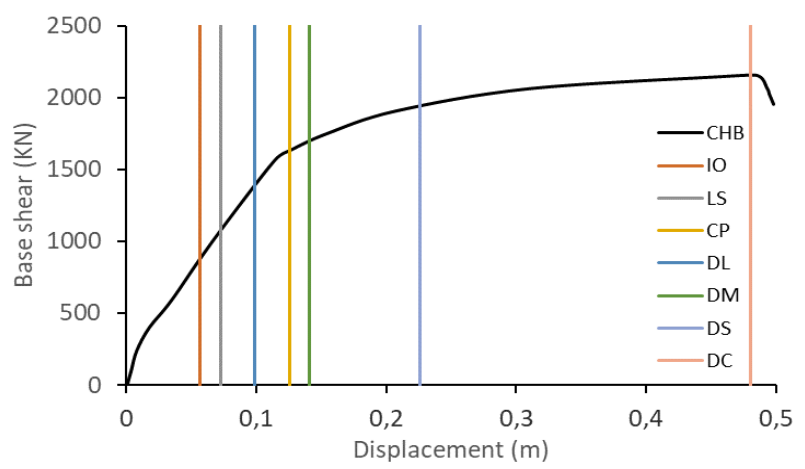

Without energy dissipators

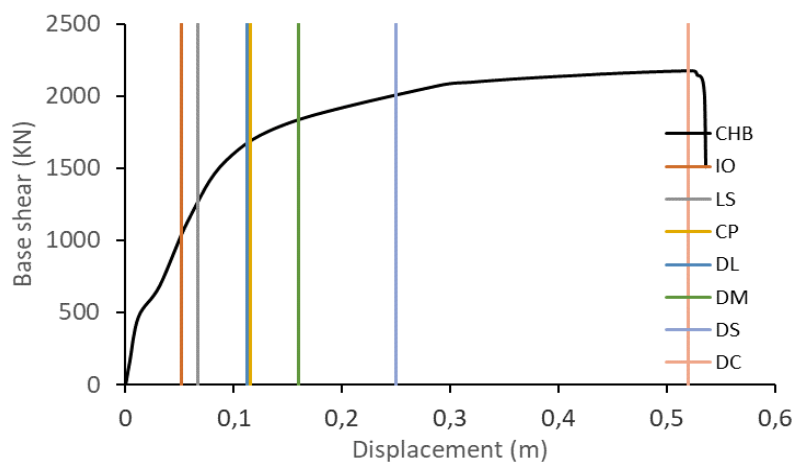

Frame with 'Chevron braces' (CHB) 

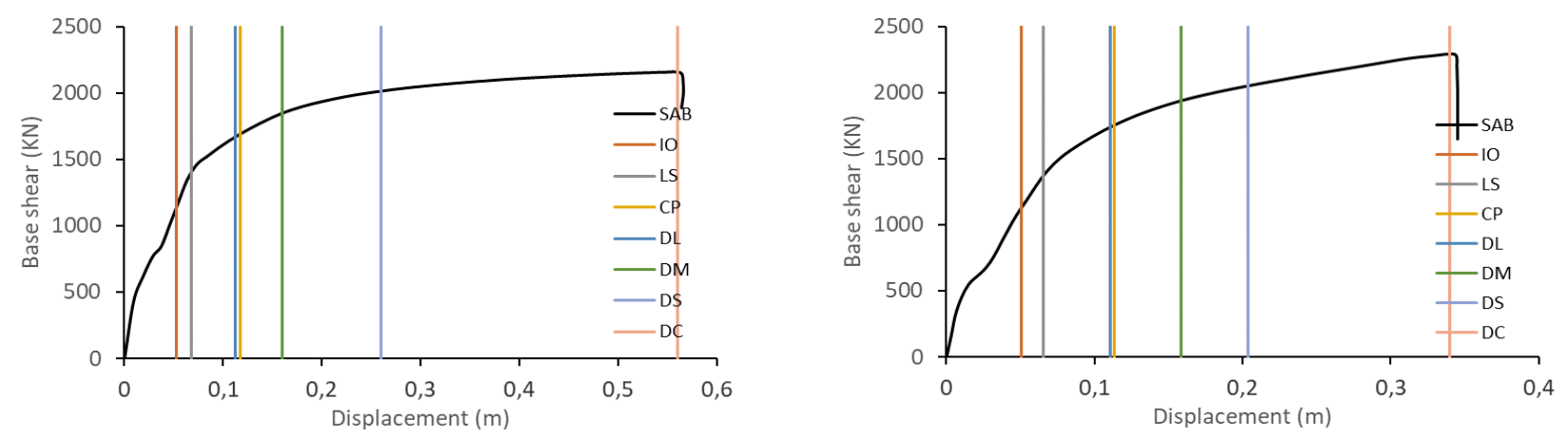

Frame with double diagonal braced 'San Andres cross' (SAB)
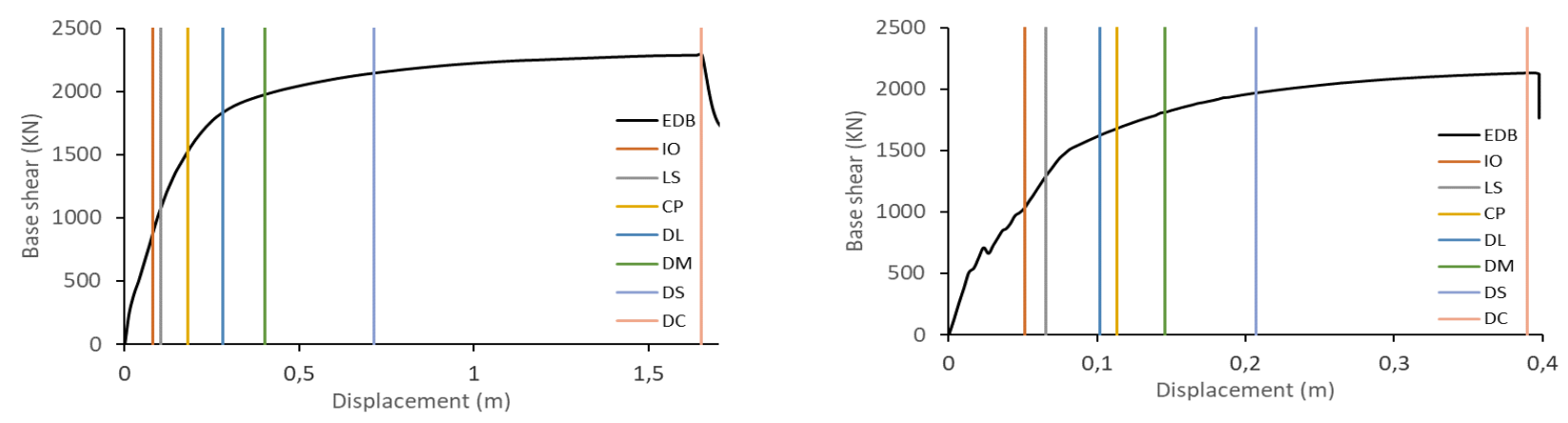

Frame with diagonal braced 'same direction' (EDB)
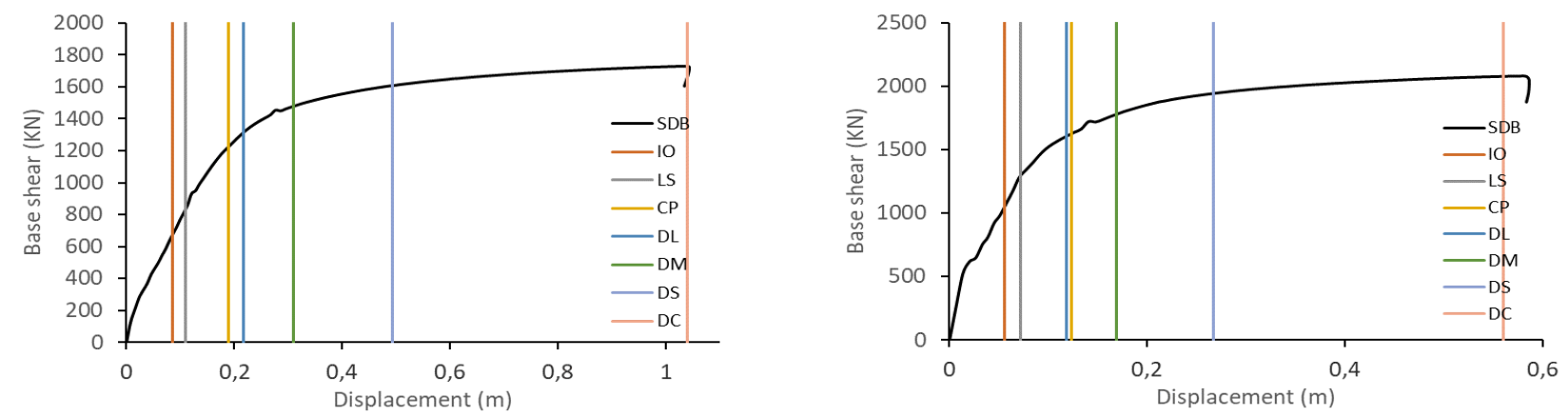

Frame with diagonal braced 'symmetrical direction' (SDB)

Fig. 10 Capacity curves of the 15-story frames (base shear - displacement)

Fig. 8, 9 and 10 show the regular, expected behavior, where the resistance capacity is greater for frames with higher seismic demands (CHB and SAB). These correspond to the frames braced without dissipators. However, ductility is higher on the dissipator frame. The effectiveness of energy dissipators increases with the height of the frame.

Tables 6, 7 and 8 represent the yield deformations $\left(d_{y}\right)$ and ultimate deformation $\left(d_{u}\right)$ obtained from the capacity curves of Fig. 8, 9 and 10. The yielding deformation $\left(d_{y}\right)$ is obtained using the graphical equality method of areas, as explained in Prestandard (2000) and Comartin et al. (1996). In addition, for each frame, the ductility $\left(\mu=d_{u} / d_{y}\right)$ is obtained, as well as the relation between the ultimate and the yield deformation. 


\begin{tabular}{|c|c|c|c|c|}
\hline Frame & $\begin{array}{c}\text { CHB } \\
\text { (with/without } \\
\text { dissipators) } \\
(\mathrm{m})\end{array}$ & $\begin{array}{c}\text { SAB } \\
\text { (with/without } \\
\text { dissipators } \\
(\mathrm{m})\end{array}$ & $\begin{array}{c}\text { EDB } \\
\text { (with/without } \\
\text { dissipators) } \\
(\mathrm{m})\end{array}$ & $\begin{array}{c}\text { SDB } \\
\text { (with/without } \\
\text { dissipators) } \\
(\mathrm{m})\end{array}$ \\
\hline $\begin{array}{c}\text { Yielding deformation } \\
\left(d_{y}\right)\end{array}$ & $0.269 / 0.096$ & $0.114 / 0.111$ & $0.733 / 0.202$ & $0.629 / 0.231$ \\
\hline $\begin{array}{c}\text { Utlimate deformation } \\
\left(d_{u}\right)\end{array}$ & $0.680 / 0.197$ & $0.317 / 0.300$ & $2.084 / 0.540$ & $1.739 / 0.601$ \\
\hline $\begin{array}{c}\text { Ductility } \\
\left(\mu=d_{u} / d_{y}\right)\end{array}$ & $2.53 / 2.04$ & $2.78 / 2.70$ & $2.84 / 2.70$ & $2.76 / 2.61$ \\
\hline
\end{tabular}

Table 6 5-story frame

\begin{tabular}{|c|c|c|c|c|}
\hline Frame & $\begin{array}{c}\text { CHB } \\
\text { (with/without } \\
\text { dissipators) } \\
(\mathrm{m})\end{array}$ & $\begin{array}{c}\text { SAB } \\
\text { (with/without } \\
\text { dissipators } \\
(\mathrm{m})\end{array}$ & $\begin{array}{c}\text { EDB } \\
\text { (with/without } \\
\text { dissipators) } \\
(\mathrm{m})\end{array}$ & $\begin{array}{c}\text { SDB } \\
\text { (with/without } \\
\text { dissipators) } \\
(\mathrm{m})\end{array}$ \\
\hline $\begin{array}{c}\text { Yielding deformation } \\
\left(d_{y}\right)\end{array}$ & $0.201 / 0.209$ & $0.167 / 0.162$ & $0.326 / 0.170$ & $0.316 / 0.200$ \\
\hline $\begin{array}{c}\text { Utlimate deformation } \\
\left(d_{u}\right)\end{array}$ & $0.482 / 0.463$ & $0.521 / 0.333$ & $0.865 / 0.413$ & $0.962 / 0.584$ \\
\hline $\begin{array}{c}\text { Ductility } \\
\left(\mu=d_{u} / d_{y}\right)\end{array}$ & $2.40 / 2.21$ & $3.12 / 2.05$ & $2.65 / 2.42$ & $3.04 / 2.92$ \\
\hline
\end{tabular}

Table 7 10-story frame

\begin{tabular}{|c|c|c|c|c|}
\hline Frame & $\begin{array}{c}\text { CHB } \\
\text { (with/without } \\
\text { dissipators) } \\
(\mathrm{m})\end{array}$ & $\begin{array}{c}\text { SAB } \\
\text { (with/without } \\
\text { dissipators } \\
(\mathrm{m})\end{array}$ & $\begin{array}{c}\text { EDB } \\
\text { (with/without } \\
\text { dissipators) } \\
(\mathrm{m})\end{array}$ & $\begin{array}{c}\text { SDB } \\
\text { (with/without } \\
\text { dissipators) } \\
(\mathrm{m})\end{array}$ \\
\hline $\begin{array}{c}\text { Yielding deformation } \\
\left(d_{y}\right)\end{array}$ & $0.141 / 0.163$ & $0.160 / 0.158$ & $0.401 / 0.145$ & $0.304 / 0.169$ \\
\hline $\begin{array}{c}\text { Utlimate deformation } \\
\left(d_{u}\right)\end{array}$ & $0.486 / 0.522$ & $0.559 / 0.339$ & $1.653 / 0.391$ & $1.032 / 0.553$ \\
\hline $\begin{array}{c}\text { Ductility } \\
\left(\mu=d_{u} / d_{y}\right)\end{array}$ & $3.44 / 3.20$ & $3.49 / 2.14$ & $4.12 / 2.68$ & $3.39 / 3.27$ \\
\hline
\end{tabular}

Table 8 15-story frame

It is noteworthy that the frames increase their ductility with the use of energy dissipators in all of the cases analyzed. The ductility ratio that exists between the braced cases and those that use dissipators increases with the height of the frames, the greatest differences being in the cases braced by means of the San Andrés cross (SAB).

\section{Dynamic analysis}

Non-linear dynamic analysis 'Time history' (Wilson et al. 1972; Vamvatsikos and Cornell 2002), was performed in discrete time using the Newmark method ' $b$ ' (Newmark 1959; Wood et al. 1980). The time discretization ( $\Delta t$ ) of the analyses was taken to be equal to the sampling period of the Lorca records in its $\mathrm{N}-\mathrm{S}$ direction $(0.01 \mathrm{~s})$. The damping of the structure was carried out using the Rayleigh model (Léger and Dussault 1992; Hevin et al. 1998), with a factor of 5\%. All calculations were carried out using the computer program (SeismoSoft 2020). The results obtained are shown in Fig. 11, 12 and 13. 


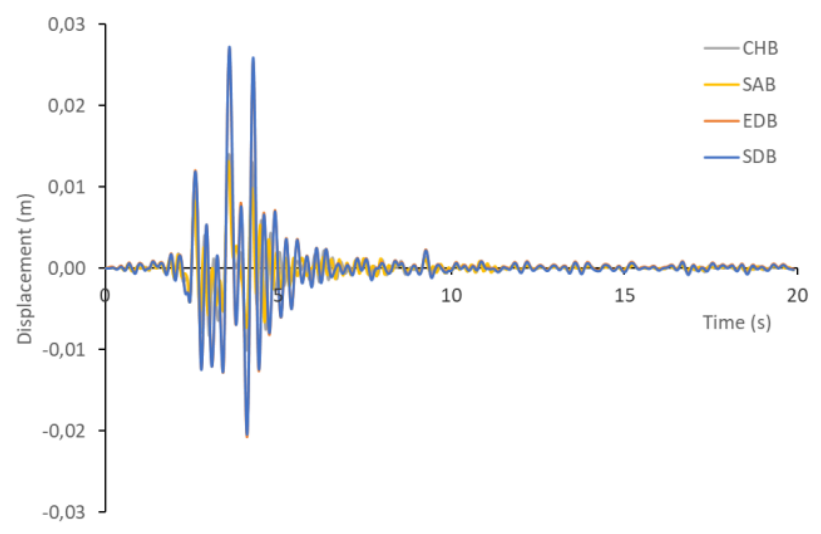

Fig. 11a Time history of the 5-story frames with dissipators

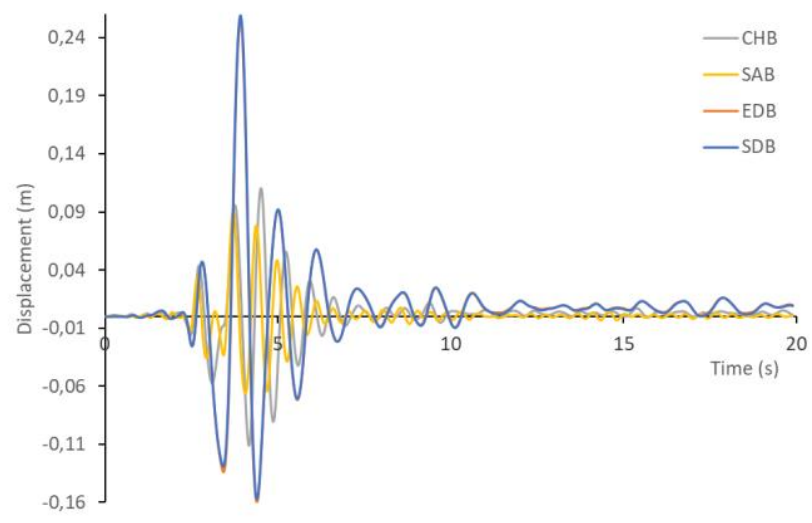

Fig. 12a Time history of the 10-story frames with dissipators

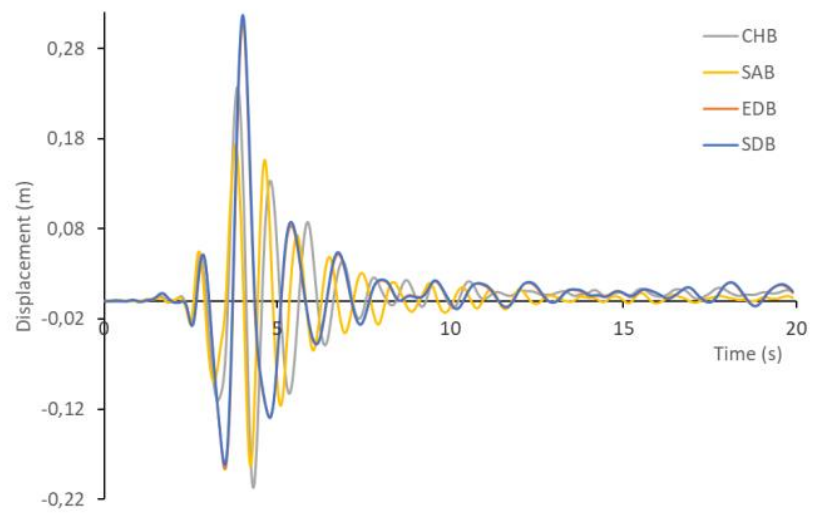

Fig. 13a Time history of the 15-story frames with dissipators

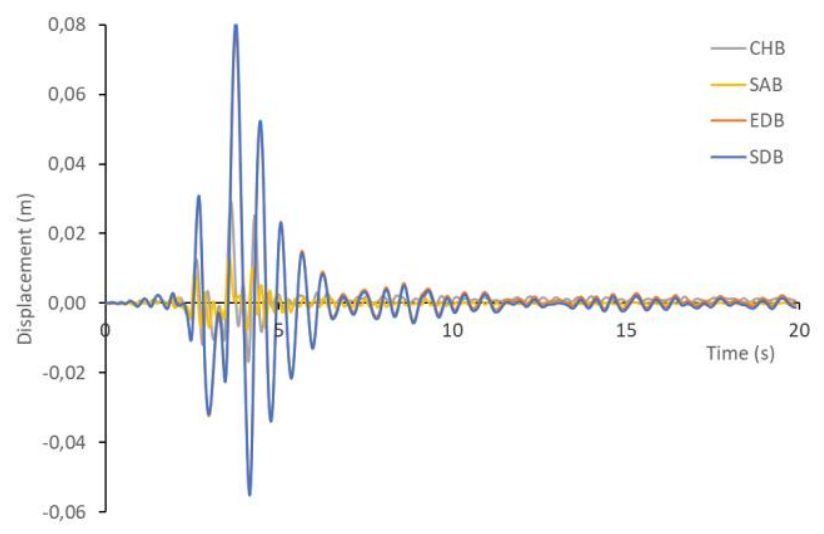

Fig. 11b Time history of the 5-story frames without dissipators

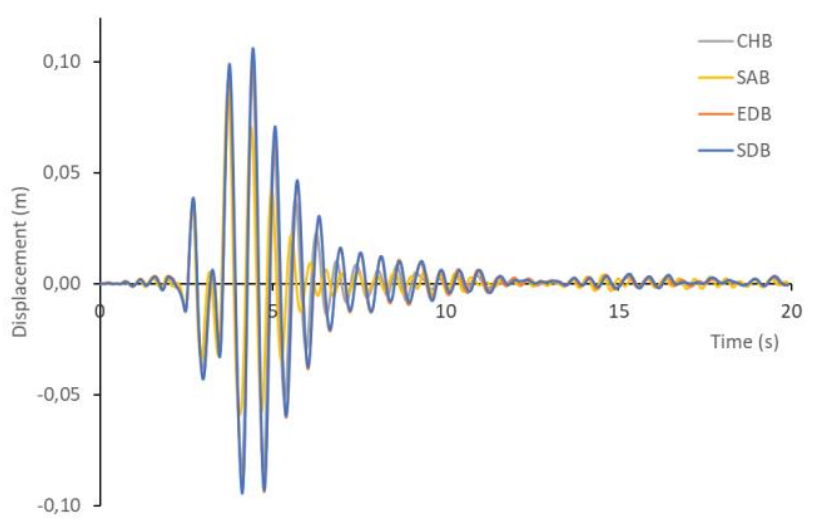

Fig. 12b Time history of the 10-story frames without dissipators

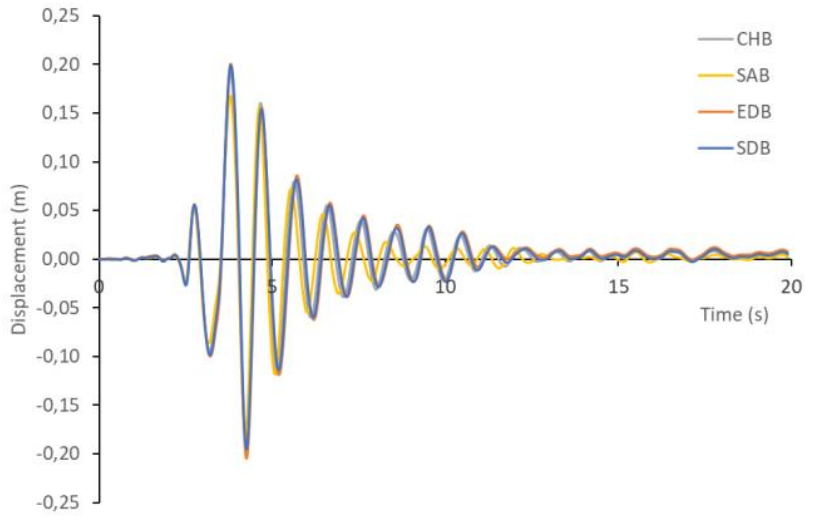

Fig. 13b Time history of the 15-story frames without dissipators

The results of the dynamic analysis 'Time history' using the Lorca record in the N-S direction of Fig. 11, 12 and 13, indicate that the best structural behaviors correspond to the lower height frames. As the frames increase in height, the efficiency of the dissipators increases, the best performance being achieved by the 15-story frames. It is noteworthy that the stiffness provided by the braces on the highest frames, negatively affect its seismic resistance behavior. On the other hand, none of the analyzed models collapsed, which shows the effectiveness that both solutions had during this earthquake. 


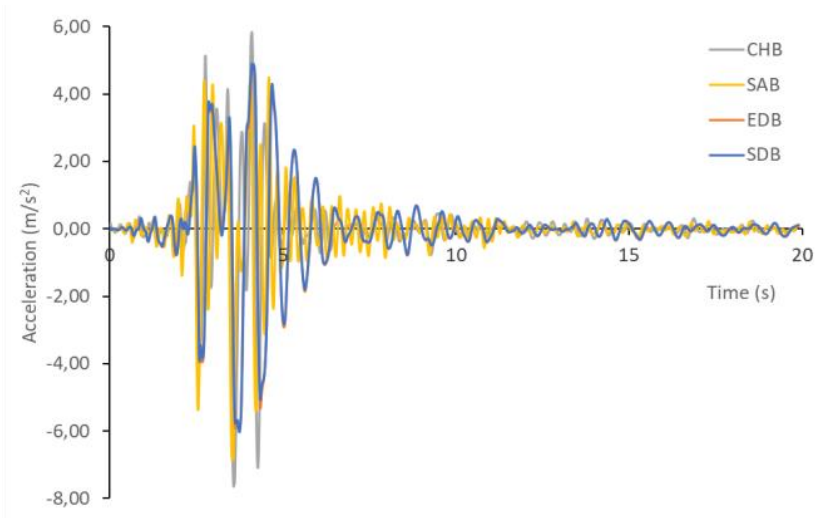

Fig. 14a Absolute acceleration of the 5-story frames with dissipators

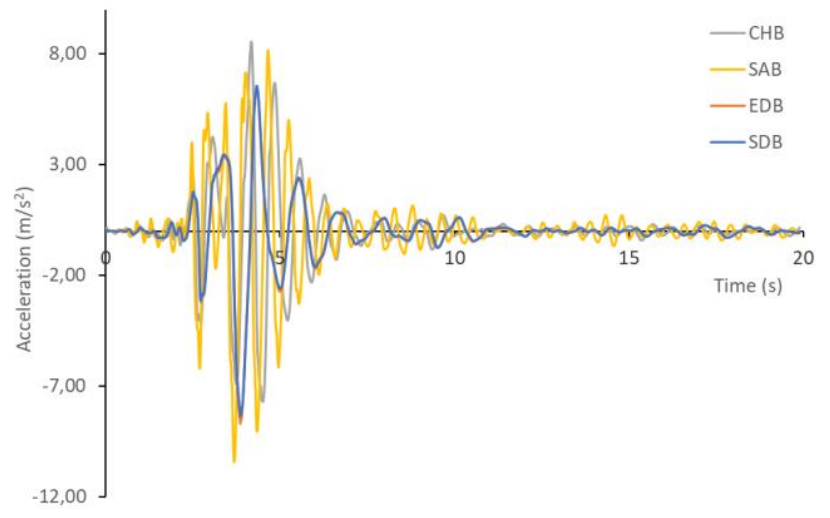

Fig. 15a Absolute acceleration of the 10-story frames with dissipators

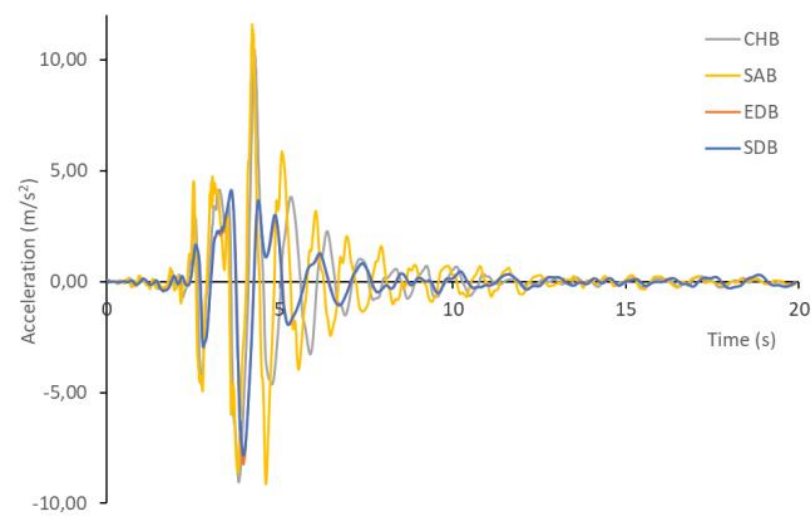

Fig. 16a Absolute acceleration of the 15-story frames with dissipators

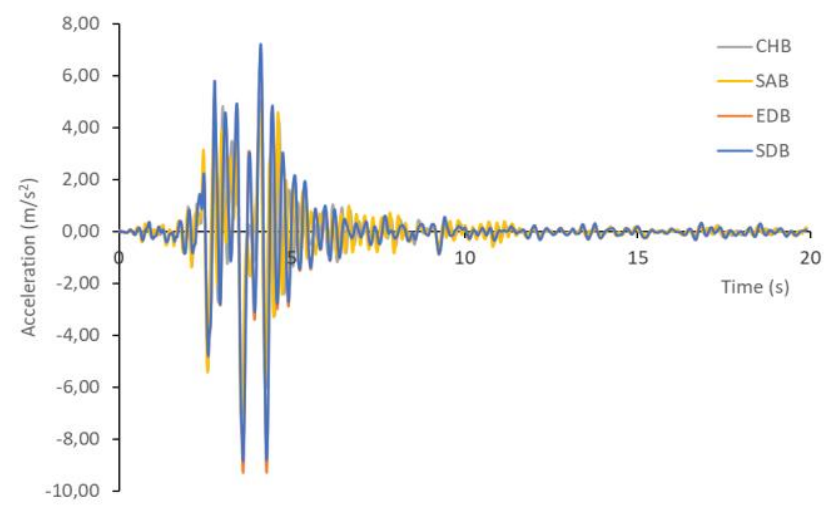

Fig. 14b Absolute acceleration of the 5-story frames without dissipators

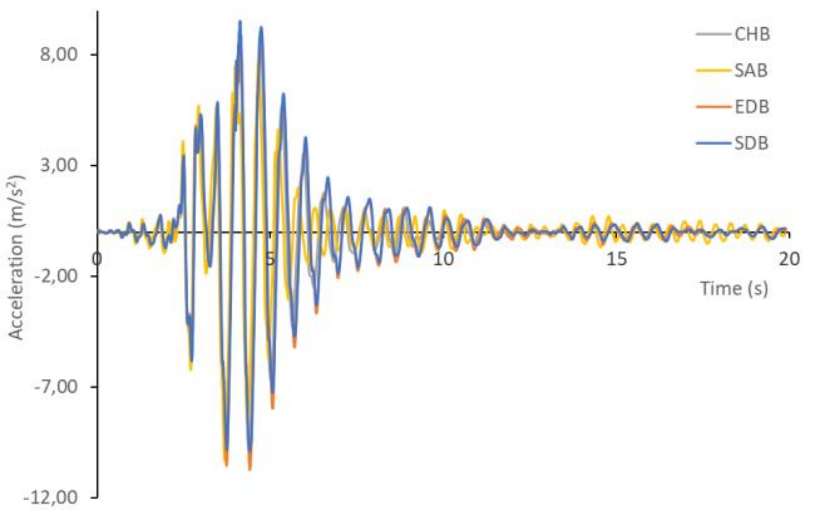

Fig. 15b Absolute acceleration of the 10-story frames without dissipators

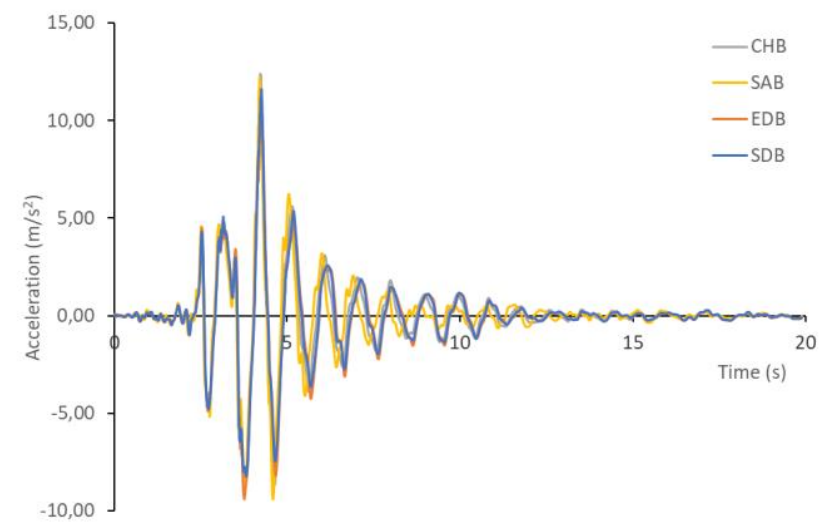

Fig. 16b Absolute acceleration of the 15-story frames without dissipators

Fig. 14, 15 and 16 represent the evolution of absolute accelerations at each instant of the Lorca record for each case. In general, it was observed that the use of dissipators significantly decreased the absolute accelerations of the frames, which lead to a significant reduction in seismic forces. This decrease became more evident as the frames increased in height. However, the increased ductility of the frames caused the displacements of the upper floors to increase in all of the cases analyzed. The maximum acceleration and displacement values of the dynamic analyses are shown in Table 9. 


\begin{tabular}{|c|c|c|c|c|c|c|c|c|}
\hline \multirow{2}{*}{ Frame } & \multicolumn{2}{|c|}{$\begin{array}{c}\text { CHB } \\
\text { (with/without dissipators) } \\
(\mathrm{m})\end{array}$} & \multicolumn{2}{|c|}{$\begin{array}{c}\text { SAB } \\
\text { (with/without dissipators) } \\
(\mathrm{m})\end{array}$} & \multicolumn{2}{|c|}{$\begin{array}{c}\text { EDB } \\
\text { (with/without dissipators) } \\
(\mathrm{m})\end{array}$} & \multicolumn{2}{|c|}{$\begin{array}{c}\text { SDB } \\
\text { (with/without dissipators) } \\
(\mathrm{m})\end{array}$} \\
\hline & $\begin{array}{l}\text { Max. Displ. } \\
\text { (m) }\end{array}$ & $\begin{array}{l}\text { Max. Accel. } \\
\left(\mathrm{m} / \mathrm{s}^{2}\right)\end{array}$ & $\begin{array}{l}\text { Max. Displ. } \\
\text { (m) }\end{array}$ & $\begin{array}{l}\text { Max. Accel. } \\
\left(\mathrm{m} / \mathrm{s}^{2}\right)\end{array}$ & $\begin{array}{l}\text { Max. Displ. } \\
\text { (m) }\end{array}$ & $\begin{array}{l}\text { Max. } \\
\text { Accel. } \\
\left(\mathrm{m} / \mathrm{s}^{2}\right)\end{array}$ & $\begin{array}{l}\text { Max. Displ. } \\
\text { (m) }\end{array}$ & $\begin{array}{l}\text { Max. } \\
\text { Accel. } \\
\left(\mathrm{m} / \mathrm{s}^{2}\right)\end{array}$ \\
\hline 5 St. & $0.029 / 0.014$ & $5.84 / 5.13$ & $0.014 / 0.013$ & $4.50 / 4.60$ & $0.078 / 0.027$ & $4.79 / 6.96$ & $0.081 / 0.027$ & $4.90 / 7.24$ \\
\hline $10 \mathrm{St}$. & $0.110 / 0.096$ & $8.53 / 8.97$ & $0.091 / 0.088$ & $8.16 / 7.67$ & $0.255 / 0.100$ & $6.44 / 8.46$ & $0.259 / 0.106$ & $6.55 / 9.52$ \\
\hline $15 \mathrm{St}$. & $0.237 / 0.191$ & $10.47 / 12.39$ & $0.173 / 0.168$ & $11.60 / 12.21$ & $0.309 / 0.200$ & $4.12 / 10.84$ & $0.317 / 0.199$ & $4.14 / 11.61$ \\
\hline
\end{tabular}

Table 9 Maximum Displacement and acceleration of frames

Table 10 shows the state of the frames, taking into account the damage states obtained in the capacity curves of the Push-over analyses using the RISK-EU method, i.e. ND (no damage), DL (light damage), DM (moderate damage) and DS (severe damage).

\begin{tabular}{|c|c|c|c|c|c|c|c|c|}
\hline \multirow{2}{*}{ Frame } & \multicolumn{2}{|c|}{ CHB } & \multicolumn{2}{c|}{ SAB } & \multicolumn{2}{c|}{ EDB } & \multicolumn{2}{c|}{ SDB } \\
\cline { 2 - 8 } & $\begin{array}{c}\text { (with } \\
\text { dissipators) }\end{array}$ & $\begin{array}{c}\text { (without } \\
\text { dissipators) }\end{array}$ & $\begin{array}{c}\text { (with } \\
\text { dissipators) }\end{array}$ & $\begin{array}{c}\text { (without } \\
\text { dissipators) }\end{array}$ & $\begin{array}{c}\text { (with } \\
\text { dissipators) }\end{array}$ & $\begin{array}{c}\text { (without } \\
\text { dissipators) }\end{array}$ & $\begin{array}{c}\text { (with } \\
\text { dissipators) }\end{array}$ & $\begin{array}{c}\text { (without } \\
\text { dissipators) }\end{array}$ \\
\hline 5 St. & ND & ND & ND & ND & ND & ND & ND & ND \\
\hline 10 St. & ND & ND & ND & ND & DL & ND & DL & ND \\
\hline 15 St.. & DM & DM & DM & DM & DL & DS & DL & DM \\
\hline
\end{tabular}

Table 10 Status damage of frames according to displacement

According to Table 10, the efficacy of the devices in the highest frames was observed, with the most effective solutions being the least rigid bracing corresponding to those with a single diagonal (EDB and SDB).

On the other hand, Tables 11, 12 and 13 represent the maximum stresses of the primary structural elements (beams and columns) and the most unfavorable braces (with $\mathrm{M}$ (moment), $\mathrm{V}$ (shear) and $\mathrm{N}$ (axial)), those belonging to the primary elements, MR (moment), VR (shear) and NR (axial), those belonging to the braced bar and FD (Force) and MD (Moment), those belonging to the energy dissipators.

\begin{tabular}{|c|c|c|c|c|}
\hline $\begin{array}{c}\text { Efforts } \\
\text { Frame }\end{array}$ & $\begin{array}{c}\text { CHB } \\
\text { (with/without } \\
\text { dissipators) } \\
(\mathrm{m})\end{array}$ & $\begin{array}{c}\text { SAB } \\
\text { (with/without } \\
\text { dissipators) } \\
(\mathrm{m})\end{array}$ & $\begin{array}{c}\text { EDB } \\
\text { (with/without } \\
\text { dissipators) } \\
(\mathrm{m})\end{array}$ & $\begin{array}{c}\text { SDB } \\
\text { (with/without } \\
\text { dissipators) } \\
(\mathrm{m})\end{array}$ \\
\hline $\mathrm{M}(\mathrm{kNm})$ & $163.59 / 134.06$ & $90.06 / 91.42$ & $211.66 / 134.49$ & $212.52 / 133.66$ \\
\hline $\mathrm{V}(\mathrm{kN})$ & $295.72 / 278.75$ & $48.06 / 47.97$ & $97.38 / 72.17$ & $96.26 / 70.98$ \\
\hline $\mathrm{N}(\mathrm{kN})$ & $607.81 / 487.68$ & $578.14 / 629.70$ & $459.54 / 829.42$ & $414.19 / 821.56$ \\
\hline $\mathrm{MR}(\mathrm{kNm})$ & $4.85 / 2.73$ & $0.67 / 0.327$ & $1.92 / 0.768$ & $2.03 / 0.748$ \\
\hline $\mathrm{VR}(\mathrm{kN})$ & $2.42 / 1.30$ & $0.36 / 0.18$ & $0.68 / 0.44$ & $0.92 / 0.48$ \\
\hline $\mathrm{NR}(\mathrm{kN})$ & $269.50 / 209.34$ & $233.36 / 191.60$ & $144.02 / 406.84$ & $140.49 / 397.69$ \\
\hline $\mathrm{FD}(\mathrm{kN})$ & 105.05 & 197.36 & 106.47 & 105.13 \\
\hline $\mathrm{MD}(\mathrm{kNm})$ & 4.73 & 0.39 & 0.58 & 0.61 \\
\hline
\end{tabular}

Table 11 Unfavorable primary elements (beams and columns) and bracing for 5-story frames

\begin{tabular}{|c|c|c|c|c|}
\hline $\begin{array}{c}\text { Efforts } \\
\text { Frame }\end{array}$ & $\begin{array}{c}\text { CHB } \\
\text { (with/without } \\
\text { dissipators) } \\
(\mathrm{m})\end{array}$ & $\begin{array}{c}\text { SAB } \\
\text { (with/without } \\
\text { dissipators) } \\
(\mathrm{m})\end{array}$ & $\begin{array}{c}\text { EDB } \\
\text { (with/without } \\
\text { dissipators) } \\
(\mathrm{m})\end{array}$ & $\begin{array}{c}\text { SDB } \\
\text { (with/without } \\
\text { dissipators) } \\
(\mathrm{m})\end{array}$ \\
\hline $\mathrm{M}(\mathrm{kNm})$ & $485.85 / 505.11$ & $365.94 / 342.16$ & $569.21 / 535.85$ & $575.23 / 520.12$ \\
\hline $\mathrm{V}(\mathrm{kN})$ & $510.52 / 695.42$ & $127.55 / 117.24$ & $145.34 / 185.68$ & $143.48 / 172.45$ \\
\hline $\mathrm{N}(\mathrm{kN})$ & $2125.22 / 2518.81$ & $2909.52 / 2813.48$ & $1682.52 / 2900.23$ & $1414.86 / 2640.71$ \\
\hline $\mathrm{MR}(\mathrm{kNm})$ & $45.02 / 43.61$ & $7.72 / 4.05$ & $22.53 / 5.93$ & $23.28 / 5.86$ \\
\hline $\mathrm{VR}(\mathrm{kN})$ & $23.04 / 20.56$ & $4.28 / 1.65$ & $6.26 / 2.98$ & $8.11 / 2.43$ \\
\hline $\mathrm{NR}(\mathrm{kN})$ & $455.39 / 516.48$ & $616.05 / 511.48$ & $310.16 / 797.20$ & $299.91 / 592.65$ \\
\hline $\mathrm{FD}(\mathrm{kN})$ & 191.29 & 498.80 & 286.62 & 280.25 \\
\hline $\mathrm{MD}(\mathrm{kNm})$ & 40.91 & 4.36 & 3.56 & 3.59 \\
\hline
\end{tabular}

Table 12 Unfavorable primary elements (beams and columns) and bracing for 10-story frames 


\begin{tabular}{|c|c|c|c|c|}
\hline $\begin{array}{c}\text { Efforts } \\
\text { Frame }\end{array}$ & $\begin{array}{c}\text { CHB } \\
\text { (with/without } \\
\text { dissipators) } \\
(\mathrm{m})\end{array}$ & $\begin{array}{c}\text { SAB } \\
\text { (with/without } \\
\text { dissipators) } \\
(\mathrm{m})\end{array}$ & $\begin{array}{c}\text { EDB } \\
\text { (with/without } \\
\text { dissipators) } \\
(\mathrm{m})\end{array}$ & $\begin{array}{c}\text { SDB } \\
\text { (with/without } \\
\text { dissipators) } \\
(\mathrm{m})\end{array}$ \\
\hline $\mathrm{M}(\mathrm{kNm})$ & $790.11 / 869.12$ & $594.84 / 551.06$ & $661.70 / 698.73$ & $770.47 / 873.48$ \\
\hline $\mathrm{V}(\mathrm{kN})$ & $738.45 / 820.96$ & $176.81 / 161.95$ & $179.18 / 198.47$ & $190.20 / 263.92$ \\
\hline $\mathrm{N}(\mathrm{kN})$ & $4034.62 / 4207.88$ & $4482.73 / 4330.02$ & $2638.78 / 4789.75$ & $2302.65 / 3641.58$ \\
\hline $\mathrm{MR}(\mathrm{kNm})$ & $103.65 / 80.31$ & $37.36 / 21.32$ & $43.32 / 21.98$ & $49.65 / 21.76$ \\
\hline $\mathrm{VR}(\mathrm{kN})$ & $55.24 / 38.16$ & $16.92 / 5.31$ & $12.21 / 5.39$ & $16.44 / 5.22$ \\
\hline $\mathrm{NR}(\mathrm{kN})$ & $635.24 / 638.47$ & $738.22 / 635.32$ & $422.10 / 964.96$ & $411.70 / 929.92$ \\
\hline $\mathrm{FD}(\mathrm{kN})$ & 367.34 & 597.95 & 352.57 & 351.92 \\
\hline $\mathrm{MD}(\mathrm{kNm})$ & 104.32 & 14.43 & 6.82 & 7.94 \\
\hline
\end{tabular}

Table 13 Unfavorable primary elements (beams and columns) and bracing for 15-story frames

The results obtained are presented in Tables 11, 12 and 13, and they show that the use of dissipators is not as effective in the 5 -story frames as using braces individually. The values obtained reflect that the effectiveness of the dissipators improves with the increase in the heights of the frames (15 heights), where the placement of these devices reduces the efforts in all of the cases studied, except for the more rigid solution (SAB). The effectiveness of the placement of these dissipators, improves with the less rigid braced solutions (EDB and SDB) and with the height of the frames, the best results being those belonging to the frames with dissipators located in the center of the diagonal brace.

\section{Conclusions}

The efficiency of the energy dissipators is improved as the frames increase in height. This efficacy is dependent on less rigid braced solutions (EDB and SDB).

In the lower height frames (5 floors), the use of braced solutions without any device improves the structural behavior. These improvements are more evident with the more rigid solutions (SAB and $\mathrm{CHB}$ ).

The ductility of all frames increases with the placement of dissipators. The increase in ductility increases with the height of the frame. The highest ductility ratio between braced and device cases occurs in the most rigid cases (CHB).

The placement of dissipators drastically reduces the absolute accelerations of the frames, especially those that are higher (15 floors). This translates into a reduction in seismic forces and, therefore, in an improvement in the seismic resistance behavior of the frames. These reductions coincide with the analysis criteria of the seismic resistance regulations.

The placement of energy dissipators using too-rigid bracing, such as the San Andrés cross (CHB), is not effective.

All of the cases would have supported the Lorca earthquake. Only the stiffer frames without dissipators and of greater height ( $\mathrm{CHB}$ and $\mathrm{SAB}$ ) would have had some problem in the structures, but they would not have collapsed. The good structural performance of the frames with diagonals and dissipators (EDB and SDB) is worth noting, they failed to laminate and were always in an elastic state.

We conclude that the dissipation of energy towards hysteretic 'fuse' devices (devices that cause the incoming energy to be concentrated in the main elements of the frame, i.e. beams and columns), due to the incoming earthquake energy in the frames, becomes more efficient as the frame increases in height.

\section{References}

ACI Committee, \& International Organization for Standardization. (2008). Building code requirements for structural concrete (ACI 318-08) and commentary. American Concrete Institute.

Adhikari, A., Rao, K. R. M., Gautam, D., \& Chaulagain, H. (2019). Seismic vulnerability and retrofitting scheme for low-tomedium rise reinforced concrete buildings in Nepal. Journal of Building Engineering, 21, 186-199.

Akiyama, H. (1985). Earthquake-resistant limit-state design for buildings. University of Tokyo Press.

ASTM, C. (1958). ASTM Standards. Philadelphia: American Society for Testing Materials..

Bae, S., \& Bayrak, O. (2008). Plastic hinge length of reinforced concrete columns. ACI Structural Journal, 105(3), 290.

Barbat, A. H., Vargas, Y. F., Pujades, L. G., \& Hurtado, J. E. (2016). Evaluación probabilista del riesgo sísmico de estructuras con base en la degradación de rigidez. Revista Internacional de Métodos Numéricos para calculo y diseño en Ingeniería, 32(1), 
$39-47$.

Bathe, K. J., \& Wilson, E. L. (1976). Numerical methods in finite element analysis. Prentice-Hall..

Benavent-Climent, A., Pujades, L., \& López-Almansa, F. (2002). Design energy input spectra for moderate-seismicity regions. Earthquake engineering \& structural dynamics, 31(5), 1151-1172.

Benavent-Climent, A., López-Almansa, F., \& Bravo-González, D. A. (2010). Design energy input spectra for moderate-tohigh seismicity regions based on Colombian earthquakes. Soil dynamics and earthquake engineering, 30 (11), 1129-1148.

Benavent-Climent, A. (2011). An energy-based method for seismic retrofit of existing frames using hysteretic dampers. Soil Dynamics and Earthquake Engineering, 31(10), 1385-1396.

Bento, R., Pinho, R., \& Bhatt, C. (2008). Nonlinear static procedures for the seismic assessment of the 3D irregular spear building. Nonlinear Static Methods for Design/Assessment of 3D Structures, 100-110..

Bin, O. J. W. (1995). Experimental comparison of the properties of friction and mild steel yielding energy dissipators and their effects on reducing vibration of structure under earthquakes $[\mathrm{J}]$. Earthquake Engineering and Engineering Vibration, 3.

Bîtcă, D., Ursu, E., \& Ioan, P. (2015). Seismic base isolators for a silo supporting structure. Mathematical Modelling in Civil Engineering, 11(2), 1-9.

Bonett Díaz, R. L. (2003). Vulnerabilidad y riesgo sísmico de edificios. Aplicación a entornos urbanos en zonas de amenaza alta y moderada. Universitat Politècnica de Catalunya.

Chopra, A. K., \& Goel, R. K. (2004). A modal pushover analysis procedure to estimate seismic demands for unsymmetricplan buildings. Earthquake engineering \& structural dynamics, 33(8), 903-927..

Clementi, F., Scalbi, A., \& Lenci, S. (2016). Seismic performance of precast reinforced concrete buildings with dowel pin connections. Journal of Building Engineering, 7, 224-238..

Code, P. (2005). Eurocode 8: Design of structures for earthquake resistance-part 1: general rules, seismic actions and rules for buildings. Brussels: European Committee for Standardization.

Comartin, C., Niewiarowski, R., \& Rojahn, C. (1996). ATC-40 Seismic evaluation and retrofit of concrete buildings. SSC 96, 1 .

Council, B. S. S. (2000). Prestandard and commentary for the seismic rehabilitation of buildings. Report FEMA-356, Washington, DC.

Decanini, L. D., \& Mollaioli, F. (2001). An energy-based methodology for the assessment of seismic demand. Soil Dynamics and Earthquake Engineering, 21(2), 113-137.

Domínguez, D., López-Almansa, F., \& Benavent-Climent, A. (2012, September). Seismic vulnerability analysis of widebeam buildings in Spain. In Proceedings of the 15th World Conference on Earthquake Engineering, Lisboa, Portugal (pp. 2428).

Domínguez, D., López-Almansa, F., \& Benavent Climent, A. (2014). Comportamiento, para el terremoto de Lorca de 11-052011, de edificios de vigas planas proyectados sin tener en cuenta la acción sísmica.

Domínguez Santos, D. J., López Almansa, F., \& Benavent Climent, A. (2015). Seismic retrofit of vulnerable buildings in Spain with hysteretic energy dissipators. In XI Congreso Chileno de Sismología e Ingeniería Sísmica: actas (pp. 1-12). Asociación Chilena de Sismología e Ingeniería Antisísmica.

Domínguez, D., López-Almansa, F., \& Benavent-Climent, A. (2016). Would RC wide-beam buildings in Spain have survived Lorca earthquake (11-05-2011)?. Engineering Structures, 108, 134-154.

Elnashai, A. S. (2001). Advanced inelastic static (pushover) analysis for earthquake applications. Structural engineering and mechanics, 12(1), 51-70.

European Committee for Standardization (CEN). (2004). Design of concrete structures-Part 1-2: General rules-Structural fire design. EN 1992 Eurocode 2.

Fajfar, P., \& Vidic, T. (1994). Consistent inelastic design spectra: hysteretic and input energy. Earthquake Engineering \& Structural Dynamics, 23(5), 523-537.

Fikri, R., Dizhur, D., Walsh, K., \& Ingham, J. (2019). Seismic performance of reinforced concrete frame with masonry infill buildings in the 2010/2011 Canterbury, New Zealand earthquakes. Bulletin of Earthquake Engineering, 17(2), 737-757. 
Fomento, M. (2008). Instrucción de hormigón estructural EHE-08. Fomento, Madrid, España.

Foraboschi, P. (2016). Versatility of steel in correcting construction deficiencies and in seismic retrofitting of RC buildings. Journal of Building Engineering, 8, 107-122.

Giner-Robles, J. L., Pérez-López, R., Silva, P. G., Rodríguez-Pascua, M. A., Martín-González, F., \& Cabañas, L. (2012). Análisis estructural de daños orientados en el terremoto de Lorca del 11 de mayo de 2011. Aplicaciones en arqueosismología. Boletín Geológico y Minero, 123(4), 503-513.

Gueguen, P. (2013). Seismic vulnerability of structures. John Wiley \& Sons.

Hadad, H. A., Calabrese, A., Strano, S., \& Serino, G. (2017). A base isolation system for developing countries using discarded tyres filled with elastomeric recycled materials. Journal of Earthquake Engineering, 21(2), 246-266..

Hevin, G., Abraham, O., Pedersen, H. A., \& Campillo, M. (1998). Characterization of surface cracks with Rayleigh waves: a numerical model. NDT \& E International, 31(4), 289-297.

Inel, M., \& Ozmen, H. B. (2006). Effects of plastic hinge properties in nonlinear analysis of reinforced concrete buildings. Engineering structures, 28(11), 1494-1502.

Kuwamura, H., Kirino, Y., \& Akiyama, H. (1994). Prediction of earthquake energy input from smoothed Fourier amplitude spectrum. Earthquake engineering \& structural dynamics, 23(10), 1125-1137.

Léger, P., \& Dussault, S. (1992). Seismic-energy dissipation in MDOF structures. Journal of Structural Engineering, 118(5), 1251-1269.

Liu, Y. L., Li, C. M., \& Yan, T. L. (2011). Dynamic Analysis of the Base Isolator Structure. In Advanced Materials Research (Vol. 143, pp. 832-836). Trans Tech Publications Ltd.

López-Almansa, F., Domínguez, D., \& Benavent-Climent, A. (2013). Vulnerability analysis of RC buildings with wide beams located in moderate seismicity regions. Engineering structures, 46, 687-702.

López-Almansa, F., Yazgan, A. U., \& Benavent-Climent, A. (2013). Design energy input spectra for high seismicity regions based on Turkish registers. Bulletin of Earthquake Engineering, 11(4), 885-912.

López-Almansa, F., \& Oller, S. (2014). Numerical solution of the equations of motion of multi-story buildings with severe nonlinearities. Revista Internacional de Métodos Numéricos para Cálculo y Diseño en Ingeniería, 30(3).

Marano, G. C., \& Greco, R. (2003). Efficiency of base isolation systems in structural seismic protection and energetic assessment. Earthquake engineering \& structural dynamics, 32(10), 1505-1531.

Martínez-Díaz, J. J., Rodríguez-Pascual, M. Á., Perez López, R., García Mayordomo, J., Giner Robles, J. L., Martín-González, F., ... \& Insua Arévalo, M. (2011). Informe geológico preliminar del terremoto de Lorca del 11 de mayo de 2011, 5.1 Mw.

Masi, A. (2003). Seismic vulnerability assessment of gravity load designed R/C frames. Bulletin of Earthquake Engineering, 1(3), 371-395.

Mazza, F. (2019). A plastic-damage hysteretic model to reproduce strength stiffness degradation. Bulletin of Earthquake Engineering, 17(6), 3517-3544.

Neuenhofer, A., \& Filippou, F. C. (1997). Evaluation of nonlinear frame finite-element models. Journal of structural engineering, 123(7), 958-966.

Newmark, N. M. (1959). A method of computation for structural dynamics. Journal of the engineering mechanics division, 85(3), 67-94.

Nuzzo, I., Losanno, D., \& Caterino, N. (2019). Seismic design and retrofit of frame structures with hysteretic dampers: a simplified displacement-based procedure. Bulletin of Earthquake Engineering, 17(5), 2787-2819.

Oterino, B. B., Medina, A. R., Escribano, J. M. G., \& Murphy, P. (2012). El terremoto de Lorca (2011) en el contexto de la peligrosidad y el riesgo sísmico en Murcia. Física de la Tierra, 24(2012), 255-287.

OU, J., \& WU, B. (2001). Experimental Study on Behavior of Composite Steel Plate Yielding Energy Dissipators and Its Effectiveness on Absorbing Seismic Vibration of Steel Tall Buildings [J]. Journal of Building Structures, 1.

Prestandard, F. E. M. A. (2000). commentary for the seismic rehabilitation of buildings (FEMA356). Washington, DC: Federal Emergency Management Agency, 7. 
Restrepo, J. I., \& Rahman, A. (2007). Seismic performance of self-centering structural walls incorporating energy dissipators. Journal of Structural Engineering, 133(11), 1560-1570.

Scott, M. H., \& Fenves, G. L. (2006). Plastic hinge integration methods for force-based beam-column elements. Journal of Structural Engineering, 132(2), 244-252.

Segués Aguasca, E., López Almansa, F., \& Rodríguez Cantalapiedra, I. (2014). Seismic protection of timber platform frame building structures with hysteretic energy dissipators: feasibility study. In Proceedings World Conference for Timber Engineering (pp. 1-11).

Seismic Standards Standing Committee. (2002). Seismic construction standard: general and building (NCSE-02). Ministry of Development: Madrid.

SeismoSoft, S. (2020). A computer program for static and dynamic nonlinear analysis of framed structures. Disponível online em: http://www. seismosoft. com.

Spacone, E., Filippou, F. C., \& Taucer, F. F. (1996). Fibre beam-column model for non-linear analysis of R/C frames: Part I. Formulation. Earthquake Engineering \& Structural Dynamics, 25(7), 711-725..

Su, L., Ahmadi, G., \& Tadjbakhsh, I. G. (1989). Comparative study of base isolation systems. Journal of engineering mechanics, 115(9), 1976-1992.

Tena-Colunga, A., \& Pérez-Osornio, M. Á. (2006). Design displacements for base isolators considering bidirectional seismic effects. Earthquake Spectra, 22(3), 803-825..

Tena-Colunga, A., Pérez-Rocha, L. E., Avilés, J., \& Cordero-Macías, C. (2015). Seismic isolation of buildings for power stations considering soil-structure interaction effects. Journal of Building Engineering, 4, 21-40.

Tena-Colunga, A., \& Hernández-Ramírez, H. (2020). Resilient seismic design of steel frames with hysteretic fuses in a codeoriented format. Journal of Building Engineering, 32, 101768.

Vamvatsikos, D., \& Cornell, C. A. (2002). Incremental dynamic analysis. Earthquake engineering \& structural dynamics, 31(3), 491-514.

Wilson, E. L., Farhoomand, I., \& Bathe, K. J. (1972). Nonlinear dynamic analysis of complex structures. Earthquake Engineering \& Structural Dynamics, 1(3), 241-252.

Wood, W. L., Bossak, M., \& Zienkiewicz, O. C. (1980). An alpha modification of Newmark's method. International Journal for numerical methods in Engineering, 15(10), 1562-1566.

Yazgan, A. U. (2012). Proposal of energy spectra for earthquake resistant design based on Turkish registers.

Yingli, L., Xibin, D., \& Ping, Y. (2007). Non-linear dynamic analysis of the base isolated structure. World Earthquake Engineering, 23(2), 107-111.. 